\title{
Invertebrates in urban areas: A review
}

\author{
ELIZABETH L. JONES and SimON R. LEATHER \\ Division of Ecology \& Evolution, Imperial College London, Silwood Park Campus, Ascot, SL5 7PY, UK; \\ e-mail: s.leather@imperial.ac.uk
}

\begin{abstract}
Key words. Bioindicators, edge effects, fragmentation, insects, invertebrates, isolation, land use, management, mowing, pollution, site age, site area, traffic, urban, urbanisation

Abstract. As urbanisation is set to continue, understanding the impact on wildlife becomes increasingly important if we are to be able to conserve biodiversity. As an excellent group of bioindicators, invertebrates can allow us to understand some of the forces in urban areas which impact upon biodiversity and wildlife populations. This paper discusses some of the trends in the abundance, diversity and richness of invertebrates related to urbanisation and the specific urban environmental and traffic factors which may be at play.
\end{abstract}

\section{INTRODUCTION}

In the UK, an urban area is defined as having a population of more than 10,000 (2009). Urban areas are made up of a high density of housing, commercial buildings, roads and other paved surfaces (Niemelä, 1999). In 2007, the UK population was greater than 60 million (National Statistics, 2007) compared with 49 million in 1996 (Department for Communities and Local Government, 2000). In $2000,89.5 \%$ of the UK population lived in urban areas compared with $84.2 \%$ in 1950 with a predicted rise to $92.4 \%$ by 2030 (Population Division Department of Economic and Social Affairs, 2001). This rising UK, and in particular urban, population will lead to rising urbanisation, with a similar trend expected globally (Botkin \& Beveridge, 1997). Urbanisation is defined as "the process by which urban ecosystems are created" (McIntyre et al., 2001). As urbanisation has occurred throughout history, habitat types within these areas have changed, meaning that wildlife is influenced. Some habitats have been lost altogether, while others have been reduced and new ones created. New habitats include urban green spaces. Urban areas are therefore a mosaic of land uses, including residential, commercial, industrial and infrastructural, interspersed with green spaces (Breuste et al., 2008). In 2001 it was estimated that UK urban parks alone covered between 127,000 and 147,000 ha (Department for Communities and Local Government, 2001). Urban domestic gardens may also be important urban green spaces and in Sheffield, UK, it is estimated that $33 \mathrm{~km}^{2}$ or $23 \%$ of the area of the city is made up of gardens (Gaston et al., 2005). Other green spaces, such as roundabouts and roadside verges, are often not considered for their contribution to the green element of an urban area which could overlook a significant amount of more natural habitat. With increasing importance placed on the inclusion of urban parks and other urban green spaces in urban planning and increasing global biodiversity interest, studies into urban green spaces are highly relevant now and for the future.
As urbanisation increases, green spaces within urban areas will become increasingly important as wildlife habitats. Urban green spaces are important for biodiversity primarily as wildlife refugia and wildlife movement corridors (Zapparoli, 1997). Furthermore they are also genetic reservoirs which is important for conservation (Zapparoli, 1997). Wildlife can develop and flourish in urban areas so they should not be considered barren wastelands (Davis, 1976; Angold et al., 2006). Many wildlife species find urban areas offer favourable conditions for their survival while other species often adapt. Urbanisation can even increase biodiversity by increasing habitat diversity (Weller \& Ganzhorn, 2004; Breuste et al., 2008). Artificial habitats, such as those found in urban areas, have been found to support $12-15 \%$ of Britain's scarce and rare species (Gibson, 1998). Urban green spaces are therefore extremely important in the urban environment and consequently it is reasonable that the ecological value of these areas should be included in urban planning and investments (Czechowski, 1982). Little is known, however, about the best methods to maximise these green spaces for use by wildlife which is an essential consideration for the future.

There is great invertebrate diversity within urban areas, including rare and important species (Owen \& Owen, 1975; Davis, 1979; Chudzicka, 1986; Zapparoli, 1997; McIntyre, 2000; McIntyre \& Hostetler, 2001; Jones, 2003; Helden \& Leather, 2004). For example, a high number of insect species have been recorded in the historical literature (since the second half of the $19^{\text {th }}$ century) in Rome, Italy, which may be due to the heterogeneity of the urban area or the suitable geographic (Fattorini, 2011). There are, however, some species which have not been recorded since the 1940s, possibly a result of loss of specialist habitats or diets or detrimental effects of urban conditions (Zapparoli, 1997). This highlights the importance of continued monitoring in urban areas. Davis (1978) noted the loss of invertebrates during the historic expansion of the area of London, UK, although the 
importance of parks, wasteland and gardens as refugia for invertebrates was highlighted. Brownfield sites, post industrial and urban, in England have been found to be important as refugia for invertebrates so the assumption that these areas are devoid of important and rare species is therefore false (Eyre et al., 2003b). This has been noted in other instances also (Owen \& Owen, 1975; McGeoch $\&$ Chown, 1997; Hornung et al., 2007).

Most authors believe urbanisation has detrimental effects on invertebrate diversity and abundance (Davis, 1978; Pyle et al., 1981; McIntyre et al., 2001). Urbanrural gradients are often used to look for changes in diversity and abundance of invertebrate groups and provide a method of investigating effects of urbanisation (McDonnell \& Pickett, 1990). Some studies have found no changes in the number of or the diversity of invertebrates with proximity to urban areas, however, and negative effects are not ubiquitous. Some examples of negative correlations of invertebrate measures in urban areas are displayed in Table 1. There are also effects on species composition in urban areas relative to non-urban, with increasing dominance of mainly generalist and opportunist species (Czechowski, 1982; Niemelä et al., 2002; Ishitami et al., 2003; Magura et al., 2004; Sadler et al., 2006; Elek \& Lövei, 2007; Fujita et al., 2008; Magura et al., 2008a). Urban areas are also more likely to show variation in species composition whereas rural areas have a more stable diversity throughout the season (Klausnitzer \& Richter, 1983). Negative correlations of invertebrate numbers in urban areas relative to non-urban, however, are not ubiquitous and some studies have shown little impact on populations or even positive correlations (Table 2).

\section{INVERTEBRATES AS URBAN BIOINDICATORS}

McIntyre (2000) summarises the importance of studying invertebrates in urban areas in five points: (1) As a diverse group they give a good indication of general biodiversity of an area. (2) Due to rapid generation times they can respond in a short time to anthropogenic changes to soil and vegetation. (3) They are easy to sample and sampling is not controversial in the public eye. (4) They are present at many trophic levels. (5) They are important in terms of sociology, agronomy and economy within habitats under anthropogenic change. In addition, McIntyre et al. (2001) also noted that invertebrates are important in cycling of organic matter, nutrient cycling, soil aeration and pollination. Thus, they influence the ecosystem function of urban areas. Furthermore, invertebrates act as a food source for higher trophic levels and changes in their numbers can influence both these organisms as well as plants (Jones \& Paine, 2006). Invertebrates act as good bioindicators compared with many other animal groups (Zapparoli, 1997; Cameron \& Leather, 2012). For insect herbivores they fulfil this role because they will respond directly to plant nutrients, defence chemicals, growth and communities (Jones \& Paine, 2006).
As a focus group of terrestrial invertebrates, carabids (Coleoptera: Carabidae) make a particularly good bioindicator group. Carabids are sensitive and respond rapidly to disturbances and environmental change and therefore act as particularly good insect indicators of habitat quality (Lövei \& Sunderland, 1996; Boscaini et al., 2000). They are present at different trophic levels (predators, herbivores, detritivores) (Lövei \& Sunderland, 1996), are found in almost every habitat type and species can be either generalists or highly specialised (Lövei \& Sunderland, 1996). This diversity allows detection of poor quality habitats. Carabids are further suited to be indicators because they are diverse and abundant, taxonomically well known and easily collected using pitfall traps (Rainio \& Niemelä, 2003). Previous work has shown that their diversity indices are correlated with those of other Coleoptera (Oliver \& Beattie, 1996) and other insect groups (Duelli \& Obrist, 1998; Cameron \& Leather, 2012). And birds (Gagne \& Fahrig, 2011) Further to their use as bioindicators, they are economically important in their own right, being significant predators of agricultural pests and should be conserved (Lövei \& Sunderland, 1996).

Much work has utilised them in this role previously and they have been used to measure effects of forest fragmentation (Desender \& Bosmans, 1998; Fujita et al., 2008), forest management (Koivula, 2002; Fuller et al., 2008), climate change (Scott \& Anderson, 2003), agricultural practices (Desender \& Bosmans, 1998; Irmler, 2003), land cover variables (Eyre et al., 2003a, 2004; Eyre \& Luff, 2004; Small et al., 2006), biodiversity (Pizzolotto, 1994; Duelli \& Obrist, 1998), pollution (Heliövaara \& Väisänen, 1993), insecticides (Frampton \& Cilgi, 1994; Walsh, 1993), environmental classification (Casale, 1990; Dufrêne et al., 1990; Eyre \& Luff, 1990; Mossakowski et al., 1990; Zulka, 1994), habitat quality (Heijerman \& Turin, 1994), as well as many more. As noted above they have also been widely utilised as indicators of urbanisation.

As a frequently used bioindicator, carabid species richness would be expected to correlate with the diversity of other groups. Moreover, sites which are good for one group would be predicted to be good for other groups. Previous work has noted that plant diversity shows a positive correlation with carabids in urban woodlands (Croci et al., 2008), in Scottish road verges (Palmer et al., 2004), in arable field margins (Asteraki, 1994) and in small forest fragments in Finland (Halme \& Niemelä, 1993). Invertebrate diversity and abundance as a whole and invertebrate predator and herbivore diversity and abundance have also been found to show this pattern (Siemann et al., 1998).

Flight is the primary mode of carabid dispersal for most species, especially into newly formed areas (den Boer, 1970; Lövei \& Sunderland, 1996). Their flying ability is dimorphic between and within species: species can be macropterous (winged), brachypterous (short winged but essentially wingless) or dimorphic (containing both macropterous and brachypterous individuals). These differ- 
TABLE 1. Examples of negative impacts of urbanisation/roadsides on invertebrate populations

\begin{tabular}{|c|c|c|c|c|c|}
\hline Invertebrate & Pattern & Location & Urban areas & Reason & Reference \\
\hline $\begin{array}{l}\text { Arthropod species } \\
\text { richness }\end{array}$ & Declined in urban & Private gardens & London, UK & $\begin{array}{l}\text { Higher temperature, lower } \\
\text { humidity, higher pollution, } \\
\text { reduced winter sunshine, } \\
\text { reduced precipitation in urban }\end{array}$ & $\begin{array}{l}\text { Davis }(1978, \\
1979)\end{array}$ \\
\hline $\begin{array}{l}\text { Native bee species } \\
\text { richness }\end{array}$ & Declined in urban & $\begin{array}{l}\text { Urban gardens com- } \\
\text { pared with reserves } \\
\text { and non-urban }\end{array}$ & \begin{tabular}{|l|} 
Bronx and East Har- \\
lem, USA, compared \\
with New Jersey and \\
New York state
\end{tabular} & $\begin{array}{l}\text { Native bees are limited by } \\
\text { urbanisation due to increased } \\
\text { habitat loss and } \\
\text { fragmentation, pollution, and } \\
\text { prevalence of exotic species }\end{array}$ & $\begin{array}{l}\text { Matteson et al. } \\
(2008)\end{array}$ \\
\hline $\begin{array}{l}\text { The number of phy- } \\
\text { tophagous insects }\end{array}$ & Declined in urban & \begin{tabular}{|l|} 
On Artemisia vul- \\
garis and Tanacetum \\
vulgare
\end{tabular} & Bonn, Germany & $\begin{array}{l}\text { Low site diversity and regular } \\
\text { flooding in urban }\end{array}$ & Schmitz (1996) \\
\hline $\begin{array}{l}\text { Butterfly diversity, } \\
\text { richness and number } \\
\text { of specialists }\end{array}$ & Declined in urban & $\begin{array}{l}\text { Secondary forests and } \\
\text { cultivated lands com- } \\
\text { pared with urban } \\
\text { parks }\end{array}$ & Tsukuba City, Japan & $\begin{array}{l}\text { High levels of human distur- } \\
\text { bance or "Intermediate distur- } \\
\text { bance hypothesis" (Connell, } \\
\text { 1978), loss of specialist host } \\
\text { plants }\end{array}$ & $\begin{array}{l}\text { Kitahara \& Fujii } \\
(1994)\end{array}$ \\
\hline $\begin{array}{l}\text { Abundance of native } \\
\text { specialist butterflies }\end{array}$ & $\begin{array}{l}\text { Declined in urban } \\
\text { between } 1910 \text { and } \\
1973\end{array}$ & Entire urban locality & Staten Island, USA & $\begin{array}{l}\text { Loss of host plants and habi- } \\
\text { tats, intrinsic cycling, mos- } \\
\text { quito insecticides, air } \\
\text { pollution }\end{array}$ & $\begin{array}{l}\text { Shapiro \& Shapiro } \\
(1973)\end{array}$ \\
\hline $\begin{array}{l}\text { Butterfly species and } \\
\text { abundance }\end{array}$ & Declined in urban & $\begin{array}{l}\text { Transects along the } \\
\text { main avenues }\end{array}$ & Porto Alegre, Brazil & $\begin{array}{l}\text { Pollution, urban climate and } \\
\text { lower vegetation cover in } \\
\text { urban localities }\end{array}$ & Ruszczyk (1986) \\
\hline $\begin{array}{l}\text { Gall occupation, } \\
\text { larval density and } \\
\text { species richness of } \\
\text { gall-inhabiting } \\
\text { Lepidoptera } \\
\end{array}$ & Declined in urban & On Acacia karroo & Pretoria, South Africa & Anthropogenic disturbance & $\begin{array}{l}\text { McGeoch \& } \\
\text { Chown (1997) }\end{array}$ \\
\hline $\begin{array}{l}\text { Elaterid species rich- } \\
\text { ness }\end{array}$ & Declined in urban & Urban green areas & Warsaw, Poland & $\begin{array}{l}\text { Loss of forest habitat and } \\
\text { clearance of wood in urban } \\
\text { sites }\end{array}$ & $\begin{array}{l}\text { Burakowski \& } \\
\text { Nowakowski } \\
(1981)\end{array}$ \\
\hline $\begin{array}{l}\text { Lepidoptera species } \\
\text { richness and abun- } \\
\text { dance }\end{array}$ & $\begin{array}{l}\text { Lower on reserva- } \\
\text { tions }\end{array}$ & $\begin{array}{l}\text { Intersection reserva- } \\
\text { tions compared with } \\
\text { grasslands, fields and } \\
\text { field verges }\end{array}$ & $\begin{array}{l}\text { Between Imatra and } \\
\text { Lappeenranta, SE } \\
\text { Finland }\end{array}$ & $\begin{array}{l}\text { Surrounding environment and } \\
\text { young age of intersections } \\
\text { meaning less vegetation and } \\
\text { low soil potassium }\end{array}$ & $\begin{array}{l}\text { Valtonen et al. } \\
\text { (2007) }\end{array}$ \\
\hline Carabid diversity & Declined in urban & $\begin{array}{l}\text { Grassland and grave- } \\
\text { yard sites }\end{array}$ & Alberta, Canada & $\begin{array}{l}\text { Habitat alterations: loss of } \\
\text { unmanaged grassland }\end{array}$ & $\begin{array}{l}\text { Hartley et al. } \\
(2007)\end{array}$ \\
\hline $\begin{array}{l}\text { Carabid species rich- } \\
\text { ness and abundance }\end{array}$ & Declined in urban & Mixed sites & $\begin{array}{l}\text { Hiroshima City, } \\
\text { Japan }\end{array}$ & $\begin{array}{l}\text { Unfavourable conditions in } \\
\text { urban areas for specialists }\end{array}$ & $\begin{array}{l}\text { Ishitami et al. } \\
(2003)\end{array}$ \\
\hline $\begin{array}{l}\text { Carabid species rich- } \\
\text { ness }\end{array}$ & Declined in urban & $\begin{array}{l}\text { Forest and woodland } \\
\text { patches }\end{array}$ & $\begin{array}{l}\text { Helsinki, Finland; } \\
\text { Sofia, Bulgaria; } \\
\text { Edmonton, Canada }\end{array}$ & $\begin{array}{l}\text { Urban sites are highly dis- } \\
\text { turbed, homogenised, } \\
\text { isolated, unfavourable to spe- } \\
\text { cialists }\end{array}$ & $\begin{array}{l}\text { Niemelä et al. } \\
(2002)\end{array}$ \\
\hline $\begin{array}{l}\text { Carabid species rich- } \\
\text { ness, abundance and } \\
\text { diversity }\end{array}$ & Declined in urban & & Helsinki, Finland & $\begin{array}{l}\text { Increased fragmentation, pol- } \\
\text { lution, temperature, recrea- } \\
\text { tional usage and exotic } \\
\text { species and decreased mois- } \\
\text { ture in urban areas plus many } \\
\text { other factors }\end{array}$ & Venn et al. (2003) \\
\hline $\begin{array}{l}\text { Carabid abundance } \\
\text { and diversity }\end{array}$ & Declined in urban & Woodland patches & Rennes, France & $\begin{array}{l}\text { Increase in built surfaces and } \\
\text { fragmentation in urban areas }\end{array}$ & Croci et al. (2008) \\
\hline $\begin{array}{l}\text { Carabid species rich- } \\
\text { ness and abundance }\end{array}$ & Declined in urban & Forest patches & Brussels, Belgium & $\begin{array}{l}\text { Urban sites are fragmented } \\
\text { and unfavourable to special- } \\
\text { ists }\end{array}$ & $\begin{array}{l}\text { Gaublomme et al. } \\
(2008)\end{array}$ \\
\hline $\begin{array}{l}\text { Carabid species rich- } \\
\text { ness }\end{array}$ & Declined in urban & $\begin{array}{l}\text { Forest and woodland } \\
\text { patches }\end{array}$ & Hamburg, Germany & $\begin{array}{l}\text { Increased isolation of urban } \\
\text { sites }\end{array}$ & $\begin{array}{l}\text { Weller \& Ganz- } \\
\text { horn (2004) }\end{array}$ \\
\hline $\begin{array}{l}\text { Carabid species rich- } \\
\text { ness and diversity }\end{array}$ & Declined in urban & $\begin{array}{l}\text { Oak-sycamore wood- } \\
\text { lands }\end{array}$ & Birmingham, UK & $\begin{array}{l}\text { High fragmentation and } \\
\text { disturbance in urban sites }\end{array}$ & $\begin{array}{l}\text { Sadler et al. } \\
(2006)\end{array}$ \\
\hline Weevil diversity & Declined in urban & $\begin{array}{l}\text { Willow species - } \\
\text { rural to urban gra- } \\
\text { dient }\end{array}$ & Beijing, China & High fragmentation & Su et al. (2011) \\
\hline
\end{tabular}


TABLE 2. Examples of neutral and positive impacts of urbanisation/roadsides on invertebrate populations.

\begin{tabular}{|c|c|c|c|c|c|c|}
\hline $\begin{array}{l}\text { Perceived } \\
\text { change }\end{array}$ & Invertebrate & Pattern & Location & Urban areas & Reason & Reference \\
\hline Neutral & $\begin{array}{l}\text { Soil arthropod } \\
\text { diversity and } \\
\text { species rich- } \\
\text { ness }\end{array}$ & No pattern & $\begin{array}{l}\text { Along the } \\
\text { roadside of an } \\
\text { expressway }\end{array}$ & $\begin{array}{l}\text { Chicago, } \\
\text { USA }\end{array}$ & $\begin{array}{l}\text { Microhabitat differences and } \\
\text { local disturbance are more } \\
\text { important than urbanisation }\end{array}$ & $\begin{array}{l}\text { Lussenhop } \\
\text { (1973) }\end{array}$ \\
\hline Neutral & $\begin{array}{l}\text { Wasp species } \\
\text { richness, abun- } \\
\text { dance and } \\
\text { community } \\
\text { composition }\end{array}$ & No pattern & $\begin{array}{l}\text { Remnant } \\
\text { habitat in urban } \\
\text { areas compared } \\
\text { with con- } \\
\text { tinuous vegeta- } \\
\text { tion }\end{array}$ & $\begin{array}{l}\text { Sydney, } \\
\text { Australia }\end{array}$ & $\begin{array}{l}\text { Wasps are resilient to urbanisa- } \\
\text { tion at this coarse scale }\end{array}$ & $\begin{array}{l}\text { Christie \& } \\
\text { Hochuli } \\
(2009)\end{array}$ \\
\hline Neutral & $\begin{array}{l}\text { Carabid abun- } \\
\text { dance and spe- } \\
\text { cies richness }\end{array}$ & No significant differences & \begin{tabular}{|l|} 
Forest and \\
woodland \\
patches along \\
an urbanisation \\
gradient \\
\end{tabular} & $\begin{array}{l}\text { Helsinki, } \\
\text { Finland }\end{array}$ & None given & $\begin{array}{l}\text { Alaruikka et } \\
\text { al. (2002) }\end{array}$ \\
\hline $\begin{array}{l}\text { Neutral/com } \\
\text { munity } \\
\text { change }\end{array}$ & $\begin{array}{l}\text { Woodlice spe- } \\
\text { cies richness, } \\
\text { abundance and } \\
\text { diversity }\end{array}$ & $\begin{array}{l}\text { No pattern, but increases in } \\
\text { urban specialist abundance, } \\
\text { with a corresponding } \\
\text { decrease in forest specialists, } \\
\text { was obscuring any pattern }\end{array}$ & $\begin{array}{l}\text { Forested sites } \\
\text { along an } \\
\text { urbanisation } \\
\text { gradient }\end{array}$ & $\begin{array}{l}\text { Debrecen, } \\
\text { Hungary }\end{array}$ & $\begin{array}{l}\text { Changes in numbers can be com- } \\
\text { plex relating to preference of dis- } \\
\text { turbance level by individual } \\
\text { species. Woodlice also will not } \\
\text { follow the intermediate distur- } \\
\text { bance hypothesis (Connell, 1978) } \\
\text { because they are decomposers }\end{array}$ & $\begin{array}{l}\text { Hornung et } \\
\text { al. (2007) } \\
\end{array}$ \\
\hline $\begin{array}{l}\text { Highest at } \\
\text { intermediate } \\
\text { levels of } \\
\text { urbanisation }\end{array}$ & $\begin{array}{l}\text { Butterfly spe- } \\
\text { cies richness }\end{array}$ & $\begin{array}{l}\text { Highest at intermediate } \\
\text { urbanisation level }\end{array}$ & $\begin{array}{l}\text { Mixed sites } \\
\text { along an } \\
\text { urbanisation } \\
\text { gradient }\end{array}$ & $\begin{array}{l}\text { Palo Alto, } \\
\text { USA }\end{array}$ & $\begin{array}{l}\text { "Intermediate Disturbance } \\
\text { Hypothesis" (Connell, 1978) }\end{array}$ & $\begin{array}{l}\text { Blair \& } \\
\text { Launer } \\
(1997)\end{array}$ \\
\hline Positive & $\begin{array}{l}\text { Species of } \\
\text { carabid }\end{array}$ & $\begin{array}{l}\text { Lower per trap in urban but } \\
\text { total caught in the urban } \\
\text { were higher }\end{array}$ & $\begin{array}{l}\text { Urban park } \\
\text { compared with } \\
\text { suburban area } \\
\text { and rural forest }\end{array}$ & Denmark & $\begin{array}{l}\text { Colonisation and invasion of } \\
\text { open habitat and generalist spe- } \\
\text { cies }\end{array}$ & \begin{tabular}{|l} 
Elek \& \\
Lövei (2007)
\end{tabular} \\
\hline Positive & $\begin{array}{l}\text { Carabid species } \\
\text { richness }\end{array}$ & $\begin{array}{l}\text { Suburban had lowest, urban } \\
\text { and rural were higher, } \\
\text { although abundance } \\
\text { decreased from rural to urban }\end{array}$ & Woodlands & $\begin{array}{l}\text { Debrecen, } \\
\text { Hungary }\end{array}$ & $\begin{array}{l}\text { Due to the presence of open } \\
\text { habitat species }\end{array}$ & $\begin{array}{l}\text { Magura et } \\
\text { al. (2004) }\end{array}$ \\
\hline Positive & $\begin{array}{l}\text { Spider species } \\
\text { richness }\end{array}$ & $\begin{array}{l}\text { Higher in urban sites com- } \\
\text { pared with suburban or rural }\end{array}$ & Forest patches & $\begin{array}{l}\text { Debrecen, } \\
\text { Hungary }\end{array}$ & $\begin{array}{l}\text { Due to the presence of open } \\
\text { habitat species from the sur- } \\
\text { rounding matric }\end{array}$ & $\begin{array}{l}\text { Magura et } \\
\text { al. (2010) }\end{array}$ \\
\hline Positive & $\begin{array}{l}\text { Butterfly spe- } \\
\text { cies richness }\end{array}$ & Higher in tropical gardens & \begin{tabular}{|l|} 
Tropical gar- \\
dens compared \\
with primary \\
and secondary \\
forest
\end{tabular} & Sierra Leone & $\begin{array}{l}\text { Pruning maintains young leaves, } \\
\text { presence of new food resources, } \\
\text { gardens combine habitats not } \\
\text { normally found together }\end{array}$ & $\begin{array}{l}\text { Owen } \\
(1971)\end{array}$ \\
\hline Positive & $\begin{array}{l}\text { Invertebrate } \\
\text { species }\end{array}$ & $\begin{array}{l}\text { Harbour many beneficial pol- } \\
\text { linators and predators of } \\
\text { agricultural pests thus } \\
\text { making them important } \\
\text { sources of natural enemies }\end{array}$ & $\begin{array}{l}\text { Roadside } \\
\text { verges }\end{array}$ & $\begin{array}{l}\text { Hertfordshire, } \\
\text { UK }\end{array}$ & Contained suitable forage & $\begin{array}{l}\text { Free et al. } \\
(1975)\end{array}$ \\
\hline Positive & \begin{tabular}{|l} 
Butterflies and \\
Burnets
\end{tabular} & Breeding populations present & $\begin{array}{l}\text { Roadside } \\
\text { verges }\end{array}$ & $\begin{array}{l}\text { Dorset and } \\
\text { Hampshire, } \\
\text { UK }\end{array}$ & $\begin{array}{l}\text { Presence of suitable host plants } \\
\text { and nectar sources }\end{array}$ & $\begin{array}{l}\text { Munguira \& } \\
\text { Thomas } \\
\text { (1992) }\end{array}$ \\
\hline Positive & Carabids & $\begin{array}{l}\text { Corridors between patches, } \\
\text { rare species, some species } \\
\text { preferred these sites over } \\
\text { larger }\end{array}$ & $\begin{array}{l}\text { Roadside } \\
\text { heathlands }\end{array}$ & Netherlands & $\begin{array}{l}\text { Presence of suitable habitat } \\
\text { nearby }\end{array}$ & $\begin{array}{l}\text { Vermeulen } \\
(1993)\end{array}$ \\
\hline Positive & $\begin{array}{l}\text { Carabid early } \\
\text { successional } \\
\text { species }\end{array}$ & $\begin{array}{l}\text { Highly disturbed roadside } \\
\text { acts as refugia }\end{array}$ & $\begin{array}{l}\text { Roadside } \\
\text { verges }\end{array}$ & $\begin{array}{l}\text { East Anglia, } \\
\text { UK }\end{array}$ & $\begin{array}{l}\text { Due to the bare ground and } \\
\text { regular disturbance of the road- } \\
\text { side environment }\end{array}$ & \begin{tabular}{|l} 
Eversham \& \\
Telfer \\
$(1994)$
\end{tabular} \\
\hline Positive & $\begin{array}{l}\text { Beetle catches/ } \\
\text { carabids }\end{array}$ & $\begin{array}{l}\text { Beetles were mainly gener- } \\
\text { alist carabids with a prefer- } \\
\text { ence for open habitat but } \\
\text { some rare and vulnerable } \\
\text { species }\end{array}$ & $\begin{array}{l}\text { Central } \\
\text { reservations }\end{array}$ & $\begin{array}{l}\text { Helsinki, } \\
\text { Finland }\end{array}$ & None given & $\begin{array}{l}\text { Koivula et } \\
\text { al. }(2005)\end{array}$ \\
\hline
\end{tabular}


ences in flight ability can be utilised to investigate the effects of site factors related to mobility. As this is within a family it allows a more controlled comparison than comparing different groups. Carabids on newly emerged habitats in Dutch polders were skewed towards small and macropterous species suggesting that these are the best invading species (Ranta \& Ås, 1982). Newly formed habitats made from sand mine spoil showed $74 \%$ of species were macropterous and $93 \%$ of individuals (Kielhorn et al., 1999). Carabid populations in unstable environments, therefore, appear to invest in flight (den Boer, 1970, 1987).

Previous work has indicated that there are fewer brachypterous species and/or individuals present within urban areas because they find it difficult to move between potentially isolated patches of habitat, and/or an increase in macropterous species and/or individuals. This has been noted in many different urban situations (Tischler, 1973; Kegel, 1990; Venn et al., 2003; Koivula et al., 2005; Sadler et al., 2006; Small et al., 2006; Fujita et al., 2008). Results for dimorphic species are more variable. In woodlands in Birmingham, UK there was no pattern in the numbers of wing dimorphic species numbers with increasing urbanisation (Sadler et al., 2006). Carabids in ruderal areas, street margins, parks and gardens in the centre of Berlin were found not to include any brachypterous species, although there were winged individuals of dimorphic species (Kegel, 1990). Carabids on central reservations of main roads in Helsinki, Finland were mainly macropterous or wing dimorphic species (Koivula et al., 2005). Dimorphic species have declined less over the last 50 to 100 years in Europe than macropterous or brachypterous species. This difference arises because the winged forms are able to disperse and colonise while the wingless forms have a high reproductive output (Kotze \& O'Hara, 2003).

Flying individuals are less likely to return than walking individuals and this active selection against flying has been previously noted as a potential for isolated islands (den Boer, 1970). It has been suggested in road enclosed forest patches in Helsinki, Finland, that carabids from remnant populations may not be able or want to escape from patches (Koivula \& Vermeulen, 2005). This may be the case for brachypterous species, especially as carabids do not like to cross tarmac and roads on foot (Mader, 1984; Mader et al., 1990; Koivula \& Vermeulen, 2005). Increasing road density positively correlated with brachypterous species in unmanaged sites in Alberta, Canada (Hartley et al., 2007), indicating that isolation is less important in this case. This explanation relies on the fact that the brachypterous species are a remnant population (Kinnunen et al., 1996), however, and has survived since these urban green spaces were formed.

Carabids vary greatly in size $[1.5$ to $35 \mathrm{~mm}$ (Luff, 2007)], a characteristic which can be utilised to study the impact of site factors. Increasing disturbance is known to decrease body size by being detrimental to larger species (Gray, 1989; Blake et al., 1994; Lövei \& Sunderland, 1996). Large species are more negatively affected by dis- turbance because of their low reproductive output, requirement for larger ranges, smaller populations and slow response to environmental change (Kotze \& O'Hara, 2003). They also have a longer life cycle and therefore need stable resources (Blake et al., 1994). There is some overlap between investigations of carabid flight ability and size because smaller species are generally more likely to be flying species (Niemelä et al., 2002; Magura et al., 2004).

Because of the increasing disturbance, high fragmentation and decrease in habitat area of urban green spaces, examples of decline in size (both in terms of species size and mean size of individuals) measured along an urbanisation gradient into urban areas are common (Czechowski, 1982; Kegel, 1990; Alaruikka et al., 2002; Niemelä et al., 2002; Ishitami et al., 2003; Magura et al., 2004, 2006; Sadler et al., 2006; Elek \& Lövei, 2007; Fujita et al., 2008).

\section{URBAN EDGE EFFECTS}

Although the majority of the edges of urban sites lie next to the road, little work has investigated edge effects on invertebrates as a whole group in urban areas. Green space at the road edge is likely to have very different abiotic and biotic conditions relative to away from the edge. There is increased temperature, decreased moisture, high emission levels, high turbulence, noise, dust, bright lights (especially from car headlights), high salinity (with associated changes in $\mathrm{pH}$ ) and changes in the composition of plants and animals which increases resource competition, at the road edge (Braun \& Flückiger, 1984; Mader, 1984; Mader et al., 1990). High road edge environmental stresses could lead to reduction in diversity according to Gray's (1989) disturbance hypothesis. There may be greater food at the site edge; specific host plants or prey items may exist there but not at the site interiors. Roadside plants can have elevated foliar nitrogen content following exposure to vehicle derived oxides of nitrogen due to direct uptake (Port \& Thompson, 1980; Spencer et al., 1988) or stress (Bolsinger \& Flückiger, 1989). Herbivores may do better on plants with a higher nitrogen content as this is frequently the limiting factor for their growth (Southwood, 1975; White, 1978; Mattson, 1980; Lightfoot \& Whitford, 1990). Therefore, changes in abundance, richness and/or diversity of invertebrate populations at the immediate edge of green space is highly likely. Table 3 shows some examples of invertebrates measured at the edge of green space and away from roads.

\section{FACTORS INFLUENCING URBAN INVEREBRATES}

\section{Site age}

There is little indication how richness and abundance may be affected by site age, and results from studies investigating this are variable (Sattler et al., 2010). McIntyre (2000) hypothesises that invertebrate diversity should increase with the age of an urbanised site, at least in part because of the addition of exotic species. Also, as sites age, there is succession of the vegetation present (Val- 
TABLE 3. Examples of the impact of the road edge on invertebrate populations.

\begin{tabular}{|c|c|c|c|c|c|c|}
\hline $\begin{array}{l}\text { Per- } \\
\text { ceived } \\
\text { impact }\end{array}$ & Invertebrate & Pattern & Location & Urban areas & Reason & Reference \\
\hline Negative & $\begin{array}{l}\text { Carabid abundance } \\
\text { and relative bio- } \\
\text { mass }\end{array}$ & Decreased & $\begin{array}{l}\text { Next to motorways } \\
\text { in agro-ecosystems }\end{array}$ & Moscow & $\begin{array}{l}\text { Food deficiencies and } \\
\text { accumulation of heavy } \\
\text { metals at the road edge }\end{array}$ & $\begin{array}{l}\text { Butovsky } \\
(1994)\end{array}$ \\
\hline Negative & $\begin{array}{l}\text { Soil invertebrate } \\
\text { abundance and } \\
\text { richness }\end{array}$ & Increased away & $\begin{array}{l}\text { Away from unpaved } \\
\text { roads }\end{array}$ & $\begin{array}{l}\text { Cherokee National } \\
\text { Forest, Tennessee, } \\
\text { USA }\end{array}$ & $\begin{array}{l}\text { Reduced depth of leaf } \\
\text { litter close to road }\end{array}$ & Haskell (2000) \\
\hline Negative & $\begin{array}{l}\text { Elaterid beetle } \\
\text { species richness }\end{array}$ & $\begin{array}{l}\text { Decreased in sites } \\
\text { closer to the road }\end{array}$ & $\begin{array}{l}\text { Park plots, housing } \\
\text { estate plots, street- } \\
\text { side plots }\end{array}$ & Warsaw, Poland & Increasing pollution & $\begin{array}{l}\text { Nowakowski } \\
\text { (1986) }\end{array}$ \\
\hline Negative & $\begin{array}{l}\text { Frequency of road } \\
\text { crossings by } \\
\text { carabids }\end{array}$ & Low levels of crossings & $\begin{array}{l}\text { Undisturbed natural } \\
\text { habitat next to roads }\end{array}$ & $\begin{array}{l}\text { Odenwald and } \\
\text { Westerwald, } \\
\text { Germany }\end{array}$ & $\begin{array}{l}\text { Changes in abiotic and } \\
\text { biotic factors making } \\
\text { roads less favourable }\end{array}$ & Mader (1984) \\
\hline Negative & $\begin{array}{l}\text { Road crossing by } \\
\text { bumblebees }\end{array}$ & Avoid flying over roads & $\begin{array}{l}\text { Conservation land } \\
\text { in a metropolitan } \\
\text { area }\end{array}$ & $\begin{array}{l}\text { Boston, Massachu- } \\
\text { setts, US }\end{array}$ & $\begin{array}{l}\text { Roads separate floral } \\
\text { patches into separate } \\
\text { populations and bees } \\
\text { have high site fidelity } \\
\end{array}$ & $\begin{array}{l}\text { Bhattacharya } \\
\text { et al. (2003) }\end{array}$ \\
\hline Negative & Dead invertebrates & Many sightings & Roadsides & $\begin{array}{l}\text { Athens in Athens } \\
\text { County, Ohio, US }\end{array}$ & $\begin{array}{l}\text { Killed by cars or dry out } \\
\text { during crossing }\end{array}$ & $\begin{array}{l}\text { Siebert \& } \\
\text { Conover } \\
(1991)\end{array}$ \\
\hline Negative & Dead invertebrates & $\begin{array}{l}\text { Many sightings, espe- } \\
\text { cially dragonflies and } \\
\text { butterflies }\end{array}$ & Roadsides & $\begin{array}{l}\text { Highways in Ban- } \\
\text { dipur National } \\
\text { Park, Nagarahole } \\
\text { National Park and } \\
\text { Mysore, India } \\
\end{array}$ & $\begin{array}{l}\text { Killed by cars or dry out } \\
\text { during crossing }\end{array}$ & $\begin{array}{l}\text { Roa \& Girish } \\
(2007)\end{array}$ \\
\hline $\begin{array}{l}\text { Negative } \\
/ \text { Posi- } \\
\text { tive }\end{array}$ & Soil arthropods & $\begin{array}{l}\text { Lower diversity but } \\
\text { higher abundance }\end{array}$ & $\begin{array}{l}\text { Roadside compared } \\
\text { with a prairie and } \\
\text { old field site away } \\
\text { from the road. }\end{array}$ & Chicago, USA & $\begin{array}{l}\text { Microhabitat differences } \\
\text { such as soil bacteria and } \\
\text { fungi and disturbance } \\
\text { are more important than } \\
\text { urbanisation gradients }\end{array}$ & $\begin{array}{l}\text { Lussenhop } \\
(1973)\end{array}$ \\
\hline $\begin{array}{l}\text { Neutral/ } \\
\text { Negative }\end{array}$ & \begin{tabular}{|l|} 
Collembola and \\
Enchytraeid worms \\
abundance, species \\
and diversity
\end{tabular} & $\begin{array}{l}\text { No patterns with dis- } \\
\text { tance from the road, } \\
\text { although Acari } \\
\text { increased in abundance } \\
\text { further from the road }\end{array}$ & Roadside verges & Scotland, UK & Altered soil $\mathrm{pH}$ & $\begin{array}{l}\text { Palmer et al. } \\
(2004)\end{array}$ \\
\hline Neutral & $\begin{array}{l}\text { Number of } \\
\text { arthropod orders }\end{array}$ & $\begin{array}{l}\text { Did not change with } \\
\text { increasing distance }\end{array}$ & $\begin{array}{l}\text { Away from a gravel } \\
\text { road }\end{array}$ & $\begin{array}{l}\text { The Barrie Islands, } \\
\text { Canada }\end{array}$ & Low resolution & \begin{tabular}{|l|} 
Luce \& Crowe \\
$(2001)$
\end{tabular} \\
\hline Neutral & $\begin{array}{l}\text { Invertebrate abun- } \\
\text { dance, number of } \\
\text { orders }\end{array}$ & $\begin{array}{l}\text { Unrelated to the dis- } \\
\text { tance from the edge }\end{array}$ & Green spaces & California, USA & $\begin{array}{l}\text { Ability of invertebrates } \\
\text { to disperse, resisting } \\
\text { edge effects and some } \\
\text { small sites are all "edge" }\end{array}$ & $\begin{array}{l}\text { Bolger et al. } \\
(2000)\end{array}$ \\
\hline Neutral & $\begin{array}{l}\text { Road crossings by } \\
\text { butterflies }\end{array}$ & $\begin{array}{l}\text { Frequent for many spe- } \\
\text { cies although turbulence } \\
\text { could influence them }\end{array}$ & Roadside verges & $\begin{array}{l}\text { Dorset and } \\
\text { Hampshire, UK }\end{array}$ & Mortalities are unlikely & $\begin{array}{l}\text { Munguira \& } \\
\text { Thomas } \\
(1992)\end{array}$ \\
\hline Positive & $\begin{array}{l}\text { Invertebrate } \\
\text { abundance }\end{array}$ & $\begin{array}{l}\text { Decreased with } \\
\text { increasing distance }\end{array}$ & $\begin{array}{l}\text { Away from a gravel } \\
\text { road }\end{array}$ & $\begin{array}{l}\text { The Barrie Islands, } \\
\text { Canada }\end{array}$ & $\begin{array}{l}\text { Represents a natural gap } \\
\text { in the environment }\end{array}$ & $\begin{array}{l}\text { Luce \& Crowe } \\
(2001)\end{array}$ \\
\hline Positive & \begin{tabular}{|l|}
$\begin{array}{l}\text { Invertebrate macro- } \\
\text { fauna diversity }\end{array}$ \\
\end{tabular} & $\begin{array}{l}\text { Increase in invertebrate } \\
\text { macrofauna diversity } \\
\text { within the first } 0.5 \mathrm{~m} \\
\text { from the road but no } \\
\text { relationships beyond }\end{array}$ & $\begin{array}{l}\text { Transects away } \\
\text { from the A40 }\end{array}$ & $\begin{array}{l}\text { Southern England, } \\
\text { UK }\end{array}$ & None givem & $\begin{array}{l}\text { Muskett \& } \\
\text { Jones (1980) }\end{array}$ \\
\hline Positive & $\begin{array}{l}\text { Isopods, hemipter- } \\
\text { ans, hymenopterans } \\
\text { and collembolans }\end{array}$ & $\begin{array}{l}\text { Greater numbers near } \\
\text { the road, with the } \\
\text { greatest differences } \\
\text { found within the first } 13 \\
\text { m }\end{array}$ & $\begin{array}{l}\text { Transects away } \\
\text { from the A40 }\end{array}$ & $\begin{array}{l}\text { Southern England, } \\
\text { UK }\end{array}$ & \begin{tabular}{|l|} 
May be escaping high \\
density of natural ene- \\
mies related to the \\
inability of natural ene- \\
mies to withstand pollu- \\
tion at the road edge
\end{tabular} & $\begin{array}{l}\text { Muskett \& } \\
\text { Jones (1980) }\end{array}$ \\
\hline Positive & \begin{tabular}{|l|} 
Abundance of \\
Coleoptera, non-ant \\
Hymenoptera, spi- \\
ders and Acari
\end{tabular} & Higher at edge & Green spaces & California, USA & $\begin{array}{l}\text { Release from natural } \\
\text { enemies }\end{array}$ & $\begin{array}{l}\text { Bolger et al. } \\
(2000)\end{array}$ \\
\hline
\end{tabular}


TABLE 3 continued.

\begin{tabular}{|c|c|c|c|c|c|c|}
\hline $\begin{array}{l}\text { Per- } \\
\text { ceived } \\
\text { impact }\end{array}$ & Invertebrate & Pattern & Location & Urban areas & Reason & Reference \\
\hline Positive & $\begin{array}{l}\text { Carabid species } \\
\text { richness }\end{array}$ & $\begin{array}{l}\text { Increased next to } \\
\text { road }\end{array}$ & $\begin{array}{l}\text { Mixed coniferous } \\
\text { forests }\end{array}$ & $\begin{array}{l}\text { Leksand, } \\
\text { Sweden }\end{array}$ & $\begin{array}{l}\text { Roadside verges are dispersal } \\
\text { corridors and act as refugia for } \\
\text { stenotopic species }\end{array}$ & Melis et al. (2010) \\
\hline Positive & Aphis pomi density & $\begin{array}{l}\text { Higher compared } \\
\text { with away from } \\
\text { reseravtion }\end{array}$ & \begin{tabular}{|l} 
On Crataegus \\
monogyna on the cen- \\
tral reservation of a \\
motorway
\end{tabular} & Switzerland & $\begin{array}{l}\text { Microclimate, especially } \\
\text { increased temperature }\end{array}$ & $\begin{array}{l}\text { Flückiger et al. } \\
\text { (1978) }\end{array}$ \\
\hline Positive & Ant diversity & $\begin{array}{l}\text { Higher at the } \\
\text { edge }\end{array}$ & Highway & $\begin{array}{l}\text { South } \\
\text { Africa }\end{array}$ & $\begin{array}{l}\text { Decreased competition between } \\
\text { ant species }\end{array}$ & $\begin{array}{l}\text { Samways et al. } \\
(1997)\end{array}$ \\
\hline Positive & Aphids & Higher & Next to the road & Poland & \begin{tabular}{|l|} 
Escaping predation \\
\end{tabular} & Przybylski (1979) \\
\hline Positive & $\begin{array}{l}\text { Aphis pomi } \\
\text { abundance }\end{array}$ & Higher & Next to motorway & Switzerland & $\begin{array}{l}\text { Decreased parasitism and preda- } \\
\text { tion by Coccinellidae, Syrphidae } \\
\text { and Cecidomyidae }\end{array}$ & $\begin{array}{l}\text { Braun \& Flückiger } \\
(1984)\end{array}$ \\
\hline Positive & $\begin{array}{l}\text { Phalera bucephala } \\
\text { (the Buff Tip moth) }\end{array}$ & Higher & $\begin{array}{l}\text { On Fagus sylvatia on } \\
\text { central reservations } \\
\text { and verges of motor- } \\
\text { ways }\end{array}$ & UK & $\begin{array}{l}\text { Enhanced plant nitrogen from } \\
\text { vehicle emissions which is bene- } \\
\text { ficial to this species }\end{array}$ & $\begin{array}{l}\text { Port \& Thompson } \\
(1980)\end{array}$ \\
\hline Positive & $\begin{array}{l}\text { Euproctis similis } \\
\text { (the Gold Tip } \\
\text { moth) }\end{array}$ & Higher & \begin{tabular}{|l} 
On Crataegus. \\
monogyna on central \\
reservations and \\
verges of motorways
\end{tabular} & UK & $\begin{array}{l}\text { Enhanced plant nitrogen from } \\
\text { vehicle emissions which is bene- } \\
\text { ficial to this species }\end{array}$ & $\begin{array}{l}\text { Port \& Thompson } \\
(1980)\end{array}$ \\
\hline Positive & $\begin{array}{l}\text { Aphis fabae } \\
\text { abundance }\end{array}$ & Higher & $\begin{array}{l}\text { On Viburnum opulus } \\
\text { and Phaseolus vul- } \\
\text { garis on motorway } \\
\text { verges }\end{array}$ & Switzerland & $\begin{array}{l}\text { Increased foliage organic } \\
\text { nitrogen and phloem sap total } \\
\text { amino acids which is beneficial } \\
\text { to this species }\end{array}$ & $\begin{array}{l}\text { Bolsinger \& } \\
\text { Flückiger (1987, } \\
\text { 1989) }\end{array}$ \\
\hline Positive & $\begin{array}{l}\text { Numbers of inver- } \\
\text { tebrate predators }\end{array}$ & $\begin{array}{l}\text { Higher at the } \\
\text { edge }\end{array}$ & Green spaces & $\begin{array}{l}\text { California, } \\
\text { USA }\end{array}$ & $\begin{array}{l}\text { High numbers of the Argentine } \\
\text { ant (Lunepithema humile) with } \\
\text { young and brood ants which are } \\
\text { a suitable prey, increased detriti- } \\
\text { vores which are prey, which in } \\
\text { turn related to greater numbers } \\
\text { of non-native grass which pro- } \\
\text { vide detritus }\end{array}$ & $\begin{array}{l}\text { Bolger et al. } \\
(2000)\end{array}$ \\
\hline Positive & Ant diversity & $\begin{array}{l}\text { Higher at the } \\
\text { edge }\end{array}$ & Highway verge & $\begin{array}{l}\text { South } \\
\text { Africa }\end{array}$ & $\begin{array}{l}\text { High numbers of insect road-kill } \\
\text { which provide a food resource }\end{array}$ & $\begin{array}{l}\text { Samways et al. } \\
(1997)\end{array}$ \\
\hline Positive & Arboreal hemiptera & $\begin{array}{l}\text { Rare species } \\
\text { found }\end{array}$ & Roundabouts & $\begin{array}{l}\text { Bracknell, } \\
\text { UK }\end{array}$ & Provision of specific host plants & $\begin{array}{l}\text { Helden \& Leather } \\
(2004)\end{array}$ \\
\hline
\end{tabular}

tonen et al., 2007) which may be related to increased habitat heterogeneity from stratification during vegetation succession (Odum, 1969; Synder \& Hendrix, 2008) which in turn increases the niches available to invertebrates. Positive correlations between site age and invertebrates were found for Lepidoptera species richness on intersection reservations in south eastern Finland (Valtonen et al., 2007), leafhopper species diversity and evenness in parks in Warsaw, Poland (Chudzicka, 1986), and spider diversity on a university campus in Japan (Okuma \& Kitazawa, 1982).

Negative correlations, however, were found for arthropod species richness in urban gardens in London (Davis, 1978) and invertebrate diversity and abundance in green spaces in California, USA (Bolger et al., 2000). This may be because invertebrates decline with time in urban fragments (Bolger et al., 2000). Species richness of carabids declined on older brownfield sites in the West Midlands, UK because of successional changes, including decreased habitat heterogeneity or vegetation succession (Small et al., 2006).

Woodlice have been previously found to be unaffected by urban site age (Bolger et al., 2000) although in general, woodlice diversity and abundance is expected to increase with site age (Synder \& Hendrix, 2008). In California, the total number of orders was also unrelated to site age (Bolger et al., 2000)

Site age was also important in determining butterfly and moth communities on road intersection reservations in south east Finland (Valtonen et al., 2007) and grasshopper and leafhopper communities in urban brownfield sites in Bremen and Berlin in Germany (Strauss \& Biedermann, 2006).

\section{Site area}

Site area is another important factor in determining invertebrate richness and abundance, particularly because it is informative to know how big green areas need to be to preserve natural levels of diversity (McIntyre, 2000). 
The general rule applies that as area of a site increases, richness and abundance also increase according to the species-area relationship (Arrhenius, 1921; Gleason, 1922; Preston, 1962; McGuinness, 1984) and individualarea relationship (Connor et al., 2000). Positive correlations have been noted for invertebrate diversity and abundance in green spaces in California, USA (although number of orders showed no correlation) (Bolger et al., 2000), spider species richness in urban forest fragments in Yokohama and Tokyo, Japan (Miyashita et al., 1998), diversity of butterflies on roadside verges in south east Finland (Saarinen et al., 2005), Lepidoptera and Agromyzidae (Diptera) species richness on roundabouts in Bracknell, UK (Keep, 2006), species richness of Diptera and Coleoptera in city parks in Cincinnati, Ohio, USA (Faeth \& Kane, 1978), number of social wasp colonies in urban gardens in Brazil (Alvarenga et al., 2010), carabid species richness in urban green spaces in Bracknell (Leather \& Helden, 2005; Stamp, 2006) and carabid species richness in road enclosed forest patches in Helsinki, Finland (Koivula \& Vermeulen, 2005).

Site area was also found to only be positively correlated with carabid species richness in rural forest sites and not urban sites along an urbanisation gradient in Brussels, Belgium (Gaublomme et al., 2008). This may be related to the presence of edge preferring carabid species was altering the expected species-area relationship (Lövei et al., 2006).

Butterfly communities on road verges in south east Finland were influenced by verge width which increased food sources and breeding habitat (Saarinen et al., 2005). Area of urban heathland patches in south-eastern Australia was important in determining the community composition of spiders and wasps and area of urban woodlands was important in determining spiders and ant communities (Gibb \& Hochuli, 2002). Area affects carabid community composition: in forest fragments in Wog Wog, Australia (Davies \& Margules, 1998), urban woodlands in Birmingham, UK (Sadler et al., 2006) and urban forests in Honshu, Japan (Fujita et al., 2008).

\section{Fragmentation, isolation and surrounding land use}

Fragmentation decreases the area of habitat available to invertebrates. Paths and other internal barriers could influence invertebrates within green space and this sort of internal fragmentation is less well studied than landscape wide fragmentation. Bumblebee movement investigated in Boston, Massachusetts, USA, found that individuals only cross roads and railways if they were displaced or forced to find new flower resources (Bhattacharya et al., 2003). Soil invertebrate abundance and richness increased away from unpaved roads in Cherokee National Forest, Tennessee, USA, probably as a result of thinning of the leaf litter (Haskell, 2000), and Luce \& Crowe (2001) found increased invertebrate abundance closer to a gravel road in the Barrie Islands, Canada. Some species have a requirement for the interior of sites and invasion from outside (Niemelä, 2001). Thus, internal paths and concrete patches could alter invertebrate communities.
Isolation of green space and the surrounding land use has been shown to be important in determining invertebrate richness and abundance (Konvicka \& Kadlec, 2011). McIntyre (2000) formed a number of hypotheses associated with isolation in urban areas: scarce or isolated habitat, especially host-plants, should have higher rates of occupation; green spaces which are near to natural habitat or on the edge of urban areas should be more easily colonised by invertebrates than sites in the city centre and therefore should show higher diversity (McIntyre, 2000). The best predictor of diversity in urban gardens in London, UK, was the proportion of land occupied by urban green spaces within $1 \mathrm{~km}$ of study sites. This was because where there was more urban green space, there was more likely to be enough suitable environment to sustain a population (Davis, 1979). Butterfly diversity in South West Manchester and Mersey Valley, Manchester, UK, decreased with increasing urban cover because of decreases in host plants and nectar sources (Hardy \& Dennis, 1999). One key factor that influences carabids in urban areas is habitat fragmentation (Magura et al., 2004, 2008a, b; Weller \& Ganzhorn, 2004; Sadler et al., 2006; Small et al., 2006; Croci et al., 2008; Fujita et al., 2008) with isolated sites with decreased species richness, abundance and/or diversity (Kinnunen et al., 1996; Weller \& Ganzhorn, 2004). The matrix of built land is also inhospitable for invertebrates to cross and thus high levels of surrounding suitable habitat is beneficial (Sadler et al., 2006; Small et al., 2006; Croci et al., 2008).

Isolation was important for carabid community composition along an urbanisation gradient in Brussels, Belgium, with greater impact on this measure than in carabid species richness (Gaublomme et al., 2008). Isolation can alter the community because less isolated sites will receive more invasions (Spence et al., 1996; Magura \& Tóthmérész, 1997; Magura et al., 2000, 2001; Niemelä, 2001; Magura, 2002; Ewers \& Didham, 2006). Вy affecting colonisation and food resources, surrounding land use can also be important in determining invertebrate communities (Blair \& Launer, 1997). Examples include: surrounding built environment for butterflies in Palo Alto, California, USA (Blair \& Launer, 1997), distance to other green space for leafhoppers in Warsaw, Poland (Chudzicka, 1986), surrounding forest and agricultural cover for butterflies on road verges and road intersection reservations in south east Finland (Saarinen et al., 2005; Valtonen et al., 2007), and surrounding brownfield sites for grasshoppers and leafhoppers in Bremen and Berlin, Germany (Strauss \& Biedermann, 2006).

\section{Pollution / Traffic}

Pollutants can influence invertebrates either directly or indirectly. Direct effects are rare (Ginevan et al., 1980; Feir \& Hale, 1983). Indirect effects generally act via their food source. For example, indirect effects on herbivores could include changes in the number of the preferred host plant, and/or changes to plant quality and surface texture but also they may be influenced by changes at higher trophic levels. In turn, changes in herbivores influence the higher trophic levels and the rest of the community 
(Flückiger et al., 2002). The exact mechanisms of how these plant-herbivore interactions work and how higher trophic interactions act are highly complex and poorly understood (Flückiger et al., 2002). According to McIntyre (2000) invertebrate diversity should decrease with increasing level of pollution.

Numerous studies have shown that roadside plants have elevated foliar nitrogen content following exposure to vehicle derived oxides of nitrogen due to direct uptake (Port \& Thompson, 1980; Spencer et al., 1988) or stress related changes in biochemistry caused by the roadside conditions (Bolsinger \& Flückiger, 1989). This in turn leads to high herbivore abundance because most groups are nitrogen limited (Southwood, 1975; White, 1978; Mattson, 1980; Lightfoot \& Whitford, 1990). Examples include, the Buff Tip moth [Phalera bucephala (Noctuidae)) and the Gold Tip moth (Euproctis similis (Lymantriidae)] on roadside Fagus sylvatica and Crataegus monogyna, respectively (Port \& Thompson, 1980), aphid numbers on potted Lolium perenne (Spencer et al., 1988) and Aphis pomi on Crataegus spp. on motorway central reservations (Flückiger et al., 1978; Braun \& Flückiger, 1984). Studies which fumigated plants with pollutants such as exhaust fumes, $\mathrm{O}_{3}, \mathrm{SO}_{2}$, $\mathrm{CO}_{2}$ and $\mathrm{NO}_{x}$ found that herbivores did better and/or showed a preference for them (Dohmen et al., 1984; Trumble et al., 1987; Warrington, 1987; Warrington et al., 1987; Chappelka et al., 1988; Houlden et al., 1990; McNeill \& Whittaker, 1990; Warrington \& Whittaker, 1990; Holopainen et al., 1991; Flückiger et al., 2002), although this was not universal (Braun \& Flückiger, 1989; Brown et al., 1993; Heliövaara \& Väisänen, 1993; Holopainen et al., 1994; Salt \& Whittaker, 1995; Masters \& McNeill, 1996; Bezemer \& Jones, 1998; Whittaker, 1999; Viskari et al., 2000; Flückiger et al., 2002).

Vehicle derived heavy metals are an important roadside pollutant. Heavy metal contamination can often result in a loss of invertebrates (Culliney et al., 1986; Tyler et al., 1989; Heliövaara \& Väisänen, 1993) and microinvertebrates in forests in New York, USA, decreased in total abundance with increasing heavy metal concentrations (Pouyat et al., 1994). Total abundance, however, is often unchanged following compensation by tolerant species. Roadsides soil with elevated heavy metal concentrations from vehicles do not always show decreased soil and litter fauna (Williamson \& Evans, 1973) but heavy metals from other sources have been correlated with declines in arthropod diversity (Tyler et al., 1989; Pouyat et al., 1994). Some arthropods, such as oribatid mites, earthworms, nematodes and Collembola, seem to be more susceptible to heavy metals (Bengtsson et al., 1985, 1986; Tyler et al., 1989) and heavy metals have been found to decrease woodlice abundance, diversity and biomass (Paoletti \& Hassall, 1999). There may also be changes in preferences: terrestrial algae near the M40 contained high concentrations of metals but grazing insect larvae preferred control algae (Sims \& Reynolds, 1999).

Surprisingly little work has been carried out on the effect of traffic on invertebrates although it can be expected that turbulence from traffic might affect flight (Braun \& Flückiger, 1984) and traffic itself could lead to insect deaths (Seibert \& Conover, 1991; Rao \& Girish, 2007). Species richness of epigenic beetles along an A type road was higher than along a highway (Bohac et al., 2004). Some examples in the literature note no influence of traffic flow on invertebrates, however: road verge populations of butterflies and burnets in Dorset and Hampshire, UK (Munguira \& Thomas, 1992; Thomas et al., 2002), richness, abundance and diversity of butterflies and diurnal moths in south east Finland (Saarinen et al., 2005) and foraging insects on verges of the M1 in Hertfordshire, UK (Free et al., 1975). Acari on roadsides in Scotland, however, had higher species richness with lower traffic although Collembola and Enchytraeid worms had higher species richness and abundance on the low traffic sites (Palmer et al., 2004). One study found that carabid species richness was higher beside a dual carriageway rather than single carriage way or non-trunk road, although this was attributed to habitat heterogeneity (Palmer et al., 2004) and another found high traffic sites had higher abundance relative to low traffic areas (Melis et al., 2010). Furthermore, traffic affected carabid community composition in road enclosed forest patches (Koivula \& Vermeulen, 2005). Traffic may also influence the microclimate of the roadside environment (previously discussed).

\section{Grass mowing}

Mowing of lawns is usually the primary management of urban green spaces. Some studies have found that certain invertebrate species prefer disturbances such as mowing (Tischler, 1973; Czechowski, 1982) although others concluded that this favoured exotic ruderal species such as the pavement ant (Tetramorium caespitum) (King \& Green, 1995). Another study actually notes that there was greatest species diversity at intermediate levels of disturbance (Connell, 1978; Blair \& Launer, 1997).

In general, however, it is considered a harmful factor because it is an intense disturbance event and would thus negatively impact on invertebrate diversity (Gray, 1989). Mowing influences both the structure and composition of vegetation (Chudzicka, 1986). Furthermore, tall grass has more invertebrate species, individuals and greater diversity and cutting is a non-selective, catastrophic event resulting in a uniform sward (Morris, 2000).

The literature is replete with examples where decreased mowing and/or longer vegetation has benefited communities. For example, butterflies and burnets on roadside verges in Dorset and Hampshire, UK, were found to decline sharply after mowing (Munguira \& Thomas, 1992) and on road verges in south east Finland, increased meadow diurnal moths were seen along road verges with taller vegetation for shelter and meadow butterflies were more common when there were more nectar sources (Saarinen et al., 2005). Other studies have compared cut and uncut plots: Acari and Enchytraeid worms had higher abundance on uncut roadsides compared with cut in Scotland, UK (Palmer et al., 2004). More detailed studies show a continuum of management intensity: snail species 
richness and abundance in urban gardens in Sheffield, UK, was negatively related to increased intensity of management (Smith et al., 2006a, b); lawns in green spaces in Warsaw, Poland, which were less intensely managed (both in terms of mowing and other management) had increased species diversity of leafhoppers (Chudzicka, 1986); higher species richness and abundance of Hemiptera in green spaces in Bracknell, UK, were found in sites with less frequent mowing (Helden \& Leather, 2004); less frequently mown sites in Bracknell had higher carabid abundance (Stamp, 2006); carabid species diversity increased with decreasing mowing in urban parks in Helsinki, Finland (Venn \& Rokala, 2005); urban areas in Warsaw, Poland where greenery was less managed, a higher diversity of carabids was found and the structure of the community resembled that of unmanaged rural sites (Czechowski, 1982); and in Berlin, Germany carabid species numbers were higher in unmanaged and weed covered urban sites (Kegel, 1990).

These increases may be due to a number of reasons: increased shelter from predators and parasitoids, increased habitat layers and therefore niches, increased food for herbivores, increased prey for predators or parasites, changes in microclimate and more sites for oviposition (Czechowski, 1982; Chudzicka, 1986; Epstein \& Kulman, 1990; Lövei \& Sunderland, 1996; Morris, 2000; Brose, 2003; Haysom et al., 2004; Helden \& Leather, 2004; Magura et al., 2004, 2008a). Further to this, mowing itself may kill off invertebrates (Czechowski, 1982), some species are sensitive to disturbance (Luff, 2007) and some species choose to migrate out of sites with frequent mowing (Hartley et al., 2007)

Gray (1989) noted that opportunistic species can become dominant with increasing disturbance. Leafhopper communities in green spaces in Warsaw, Poland, were determined by intensity of grass management, with more intense management leading to dominance by a few species (Chudzicka, 1986). Diurnal moth communities on road verges in south east Finland were affected by intensity of mowing (Saarinen et al., 2005). Much work has indicated the increases in winged and small carabid species with increasing disturbance such as mowing (den Boer, 1970; Gray, 1989; Blake et al., 1994; Venn \& Rokala, 2005; Hartley et al., 2007), for example the size of carabids in uncut areas of urban parks in Helsinki, Finland were found to increase relative to cut areas (Venn \& Rokala, 2005). Venn \& Rokala (2005) found carabids formed two different communities types in mown lawns (dominated by thermophilic grassland species) and in uncut meadows (dominated by deciduous woodlands species).

Mowing also affects the structure and resources of grassland which has been found to be important for butterflies in Singapore (Koh \& Sodhi, 2004), invertebrates in green space in Melbourne, Australia (Kazemi et al., 2009), for grasshoppers and leafhoppers in urban brownfields in Bremen and Berlin, Germany (Strauss \& Biedermann, 2006), for nectar resources for butterflies on road verges in south east Finland (Saarinen et al., 2005), and for vegetation height and nectar resources for butterflies and moths on intersection reservations in south east Finland (Valtonen et al., 2007).

\section{Cultivated plants, other exotics and green roofs}

Urban landscapes are characterised by a large proportion of non-native plant species (Owen, 1983; Smith et al, 2006; Shrewsbury \& Leather, 2012), and this can have profound effects on habitat diversity and insect occurrence (Gaston et al., 2005; Raupp et al., 2010). This can operate in two ways, native insects utilising non-native plants, e.g. the butterfly Poanes melane is largely dependent on the Australian grass, Rytidosperma racemosum in urban and suburban California (Shapiro, 2006), and it has been estimated that over $40 \%$ of butterflies in these settings utilise non-native plants as hosts (Shapiro, 2002; Graves \& Shapiro, 2003). Conversely invasive insect pests can be introduced via nursery plants as evidenced by the establishment of the African Lycaenid, Cacyreus marshalli in Majorca (Monteys, 1992).

The increasing use of green roofs in towns and cities (Hunter \& Hunter, 2008) has also led to an increase in insect diversity in what would otherwise be unsuitable habitats (Kadas, 2011). Green roofs support a wide variety of invertebrates and although probably no more diverse than other brown-field sites can act as additional refugia for arthropod biodiversity in cities (McIvor \& Lundholm, 2011).

\section{CONCLUSIONS}

This paper aims to highlight just some of the factors which may influence the ability of green space to be wildlife reserves and how invertebrate bioindicators could be used in studies such as this. It is obvious that there is potential for increasing the effectiveness of these sites to act as reserves and this will become increasingly important with rising urbanisation. Appropriate management can not only retain biodiversity at current levels, but can increase the numbers of rare and uncommon species and increase the abundance of many species.

\section{REFERENCES}

AlaruikKa D., Kotze D.J., Matveinen K. \& Niemelä J. 2002: Carabid beetle and spider assemblages along a forested urbanrural gradient in southern Finland. J. Insect Conserv. 6: 195-206.

Alvarenga R.D., de Castro M.M., Santos-Prezoto H.H. \& Prezoto F. 2010: Nesting of social wasps (Hymenoptera, Vespidae) in urban gardens in Southeastern Brazil. Sociobiology 55: 445-452.

Angold P.G., Sadler J.P., Hill M.O., Pullin A., Rushton S., Austin K., Small E., Wood B., Wadsworth R., Sanderson R. \& Thompson K. 2006: Biodiversity in urban habitat patches. Sci. Total Environ. 360: 196-204.

Arrhenius O. 1921: Species and area. J. Ecol. 9: 95-99.

AsterAKI E. 1994: The carabid fauna of sown conservation margins around arable fields. In Desender K., Dufrêne M., Loreau M., Luff M.L. \& Maelfait J.-P. (eds): Carabid Beetles: Ecology and Evolution. Kluwer, Dordrecht, pp. 229-233.

Bengtsson G., Gunnarsson T. \& Rundgren S. 1985: Influence of metals on reproduction, mortality and population growth in 
Omychiurus armatus (Collembola). J. Appl. Ecol. 22: 967-978.

Bengtsson G., Gunnarsson T. \& Rundgren S. 1986: Effects of metal pollution on the earthworm Dendrobaena rubida (Sav.) in acidified soils. Water Air Soil Pollut. 28: 361-383.

Bezemer T.M. \& Jones T.H. 1998: Plant-insect interactions in elevated atmospheric $\mathrm{CO}_{2}$ : quantitative analyses and guild effects. Oikos 82: 212-222.

Bhattacharya M., Primack R.B. \& Gerwein J. 2003: Are roads and railroads barriers to bumblebee movement in a temperate suburban conservation area? Biol. Conserv. 109: 37-45.

Blair R.B. \& LAUner A.E. 1997: Butterfly diversity and human land use: species assemblages along an urban gradient. Biol. Conserv. 80: 113-125.

Blake S., Foster G.N., Eyre M.D. \& Luff M.L. 1994: Effects of habitat type and grassland management practises on the body size distribution of carabid beetles. Pedobiologia 38: $502-512$.

Bohac J., Hanouskova I. \& MatejKa K. 2004: Effect of habitat fragmentation due to traffic impact in different intensity on epigeic beetle communities in cultural landscapes of the Czech Republic. Ekologia (Bratislava) 23: 35-46.

Bolger D.T., Suarez A.V., Crooks K.R., Morrison S.A. \& CASE T.J. 2000: Arthropods in urban habitat fragments in southern California: area, age and edge effects. Ecol. Appl. 10: $1230-1248$.

BOlSINGER M. \& FlÜCKIGER W. 1987: Enhanced aphid infestation at motorways: the role of ambient air pollution. Entomol. Exp. Appl. 45: 237-243.

Bolsinger M. \& FlÜCKIGER W. 1989: Ambient air-pollution induced changes in amino-acid pattern of the phloem sap of host plants - relevance to aphid infestation. Environ. Pollut. 56: $209-216$.

Boscaini A., Franceschini A. \& Maiolini B. 2000: River ecotones: carabid beetles as a tool for quality assessment. Hydrobiologia 422/423: 173-181.

BotKin D.B. \& Beveridge C.E. 1997: Cities as environments. Urban Ecosyst. 1: 3-19.

BRAUN S. \& FLÜCKIGER W. 1984: Increased population of the aphid Aphis pomi at a motorway: Part 1 - field evaluation. Environ. Pollut. (A) 33: 107-120.

Braun S. \& FlÜCKIGER W. 1989: Effect of ambient ozone and acid mist on aphid development. Environ. Pollut. 56: 177-187.

Breuste J., Niemelä J. \& Snep R.P.H. 2008: Applying landscape ecological principles in urban environments. Landsc. Ecol. 23: $1139-1142$.

BRose U. 2003: Bottom-up control of carabid beetle communities in early successonal wetlands: mediated by vegetation structure or plant diversity? Oecologia 135: 407-413.

Brown V.C., Ashmore M.R. \& McNeill S. 1993: Experimental investigations of the effects of air-pollutants on aphids on conifer trees. Forstwissensch. Zentralbl. 112: 128-132.

BurakowsKi B. \& NowaKowsKi E. 1981: Click beetles (Coleoptera, Elateridae) of Warsaw and Mazovia. Memorab. Zool. 34: $165-180$

ButovsKY R.O. 1994: Carabids in roadside ecosystems: perspective of bioindication. In Desender K., Dufrêne M., Loreau M. Luff M.L. \& Maelfait J.-P. (eds): Carabid Beetles: Ecology and Evolution. Kluwer, Dordrecht, pp. 241-246.

Cameron K.H. \& Leather S.R. 2012: How good are carabid beetles (Coleoptera, Carabidae) as indicators of invertebrate abundance and order richness? Biodiv. Conserv. 21: 763-779.
CASAle A. 1990: Carabid communities of aquatic and semiaquatic environments in North-western Italy: their role as ecological indicators. In Stork N.E. (ed.): The Role of Ground Beetles in Ecological and Environmental Studies. Intercept, Andover, pp. 349-352.

Chappelka A.H., Kraemer M.E., Mebrahtu T.M. \& Benepal P.S. 1988: Effects of ozone on soybean resistance to Mexican bean beetle feeding preference and larval antibiosis. Environ. Pollut. 53: 418-419.

Christie F.J. \& Hochuli D.F. 2009: Responses of wasp communities to urbanizations: effects on community resilience and species diversity. J. Insect Conserv. 13: 213-221.

ChUdzicka E. 1986: Structure of leafhopper (Homoptera, Auchenorrhyncha) communities in the urban green of Warsaw. Memorab. Zool. 42: 67-99.

ConNell J.H. 1978: Diversity in tropical rain forests and coral reefs. Science 199: 1302-1310.

Connor E.F., Courtney A.C. \& Yoder J.M. 2000: Individualsarea relationships: the relationship between animal population density and area. Ecology 81: 734-748.

Croci S., Butet A., Georges A., Aguejdad R. \& Clergeau P. 2008: Small urban woodlands as biodiversity conservation hot spot: a multi-taxon approach. Ladsc. Ecol. 23: 1171-1186.

Culliney T.W., Pimentel D. \& Lisk D.J. 1986: Impact of chemically contaminated sewage sludge on the collard arthropod community. Environ. Entomol. 15: 826-833.

Czechowski W. 1982: Occurrence of carabids (Coleoptera, Carabidae) in the urban greenery of Warsaw according to the land utilization and cultivation. Memorab. Zool. 39: 3-108.

DAVIES K.F. \& MARGULES C.R. 1998: Effects of habitat fragmentation on carabid beetles: experimental evidence. J. Anim. Ecol. 67: 460-471.

DAvis B.N.K. 1976: Wildlife, urbanisation and industry. Biol. Conserv. 10: 249-291.

DAvis B.N.K. 1978: Urbanisation and the diversity of insects. In Mound L.A. \& Waloff N. (eds): Diversity of Insect Faunas. Blackwell, Oxford, pp. 126-138.

DAVIS B.N.K. 1979: The ground arthropods of London gardens. London Natur. 58: 15-24.

DEN Boer P.J. 1970: On the significance of dispersal power for populations of carabid-beetles (Coleoptera, Carabidae). Oecologia 4: 1-28.

DEN BoER P.J. 1987: On the turnover of carabid populations in changing environments. Acta Pytopathol. Entomol. Hung. 22: 71-83.

Department for Communities and Local Government 2000: Our Towns and Cities: The Future - Full Report. Department for Communities and Local Government, London [Online] Available from: http://www.communities.gov.uk/documents/ citiesandregions/pdf/154869 [Accessed November 2006].

Department for Communities and Local Government 2001: Green Space, Better Places: The Interim Report - Full Report. Department for Communities and Local Government, London [Online] Available from: http://www.communities. gov.uk/documents/communities/pdf/154953 [Accessed November 2007].

Desender K. \& Bosmans R. 1998: Ground beetles (Coleoptera, Carabidae) on set-aside fields in the Campine region and their importance for nature conservation in Flanders (Belgium). Biodivers. Conserv. 7: 1485-1493.

Dohmen G.P., McNeill S. \& Bell J.N.B. 1984: Air pollution increases Aphis fabae pest potential. Nature 307: 52-53.

Duelli P. \& OBRIST M.K. 1998: In search of the best correlates for local organismal biodiversity in cultivated areas. Biodivers. Conserv. 7: 297-309. 
Dufrêne M., Baguette M., Desender K. \& Maelfait J.-P. 1990: Evaluation of carabids as bioindicators: a case study in Belgium. In Stork N.E. (ed.): The Role of Ground Beetles in Ecological and Environmental Studies. Intercept, Andover, pp. 377-381.

Elek Z. \& LöveI G.L. 2007: Patterns in ground beetle (Coleoptera: Carabidae) assemblages along an urbanisation gradient in Denmark. Acta Oecol. 32: 104-111.

Epstein M.C. \& Kulman H.M. 1990: Habitat distribution occurrence of carabid beetles in east-central Minnesota. Am. Midland Natur. 123: 209-225.

Eversham B.C. \& Telfer M.G. 1994: Conservation value of roadside verges for stenotopic heathland Carabidae: corridors or refugia? Biodivers. Conserv. 3: 538-545.

Ewers R.M. \& Didham R.K. 2006: Confounding factors in the detection of species responses to habitat fragmentation. Biol. Rev. 81: 117-142.

EYRE M.D. \& LufF M.L. 1990: A preliminary classification of European grassland habitats using carabid beetles. In Stork N.E. (ed.): The Role of Ground Beetles in Ecological and Environmental Studies. Intercept, Andover, pp. 227-236.

Eyre M.D. \& LufF M.L. 2004: Ground beetle species (Coleoptera, Carabidae) associations with land cover variables in northern England and southern Scotland. Ecography 27: 417-426.

Eyre M.D., Luff M.L., Staley J.R. \& Telfer M.G. 2003a: The relationship between British ground beetles (Coleoptera, Carabidae) and land cover. J. Biogeogr. 30: 719-730.

Eyre M.D., Luff M.L. \& Woodward J.C. 2003b: Beetles (Coleoptera) on brownfield sites in England: An important conservation resource? J. Insect Conserv. 7: 223-231.

Eyre M.D., Rushton S.P., Luff M.L. \& Telfer M.G. 2004: Predicting the distribution of ground beetle species (Coleoptera, Carabidae) in Britain using land cover variables. J. Environ. Manag. 72: 163-174.

FAETH S.H. \& Kane T.C. 1978: Urban biogeography: City parks as islands for Diptera and Coleoptera. Oecologica 32: 127-133.

FATTORINI S. 2011: Influence of island geography, age and landscape on species composition in different animal groups. $J$. Biogeogr. 38: 1318-1329.

Feir D. \& Hale R. 1983: Growth and reproduction of an insect model in controlled mixtures of air pollutants. Int. J. Environ. Stud. 20: 223-228.

FlüCKIGER W., Braun S. \& HiltbrunNer E. 2002: Effects of air pollution on biotic stress. In Bell J.N.B. \& Treshow M. (eds): Air Pollution and Plant Life. 2nd ed. John Wiley and Sons, Chichester, pp. 379-406.

FlüCKiger W., Oertli J.J. \& Baltensweiler W. 1978: Observations of an aphid infestation on hawthorn in the vicinity of a motorway. Naturwissenschaften 65: 654-655.

Frampton G.K. \& ÇILGI T. 1994: Long-term effects of pesticides on Carabidae in U.K. farmland: some initial results from the "SCARAB" Project. In Desender K., Dufrêne M., Loreau M., Luff M.L. \& Maelfait J.-P. (eds): Carabid Beetles: Ecology and Evolution. Kluwer, Dordrecht, pp. 433-438.

Free J.B., Gennard D., Stevenson J.H. \& Williams I.H. 1975: Beneficial insects present on a motorway verge. Biol. Conserv. 8: 61-72.

Fujita A., Maetro K., Kagawa Y. \& Ito N. 2008: Effects of forest fragmentation on species richness and composition of ground beetles (Coleoptera: Carabidae and Brachinidae) in urban landscapes. Entomol. Sci. 11: 39-48.

Fuller R.J., Oliver T.H. \& LeAther S.R. 2008: Forest management effects on carabid beetle communities in coniferous and broadleaved forests: implications for conservation. Insect Conserv. Divers. 1: 242-252.

Gagne S.A. \& Fahrig L. 2011: The birds and beetles show similar resposnes to urbanization. Ecol. Appl. 21: 2297-2312.

Gaston K.J., Warren P.H., Thompson K. \& Smith R.M. 2005: Urban domestic gardens (IV): the extent of the resources and its associated features. Biodiv. Conserv. 14: 3327-3349.

Gaublomme E., Hendrickx F., Dhuyvetter H. \& Desender K. 2008: The effects of forest patch size and matrix type on changes in carabid beetle assemblages in an urbanized landscape. Biol. Conserv. 141: 2585-2596.

Gibi H. \& Hochuli D.F. 2002: Habitat fragmentation in an urban environment: large and small fragments support different arthropod assemblages. Biol. Conserv. 106: 91-100.

GiBson C.W.D. 1998: Brownfield: Red Data. The Values Artifical Habitats have for Uncommon Invertebrates. No. $273-$ English Nature Research Reports. English Nature, Oxford, 47 pp.

Ginevan M.E., Lane D.D. \& Greenberg L. 1980: Ambient air concentration of sulfur dioxide affects flight activity in bees. Proc. Nat. Acad. Sci. USA 77: 5631-5633.

GLEASON H.A. 1922: On the relation between species and area. Ecology 3: 158-162.

Graves S.D. \& Shapiro A.M. 2003:. Exotics as host plants of the Californian butterfly fauna. Biol. Conserv. 110: 413-433.

GraY J.S. 1989: Effects of environmental stress on species rich assemblages. Biol. J. Linn. Soc. 37: 19-32.

Halme E. \& Niemelä J. 1993: Carabid beetles in fragments of coniferous forest. Ann. Zool. Fenn. 30: 17-30.

HaRDY P.B. \& DenNIS R.L.H. 1999: The impact of urban development on butterflies within a city region. Biodiv. Conserv. 8: $1261-1279$.

Hartley D.J., Koivula M.J., Spence J.R., Pelletier R. \& Ball G.E. 2007: Effects of urbanization on ground beetle asseblages (Coleoptera, Carabidae) of grassland habitats in western Canada. Ecography 30: 673-684.

HASKell D.G. 2000: Effects of forest roads on macroinvertebrate soil fauna of the Southern Appalachian Mountains. Conserv. Biol. 14: 57-63.

Haysom K.A., McCracken D.I., Foster G.N. \& Sotherton N.W. 2004: Developing grassland conservation headlands: response of carabid assemblage to different cutting regimes in a silage field edge. Agric. Ecosyst. Environ. 102: 263-277.

Heijerman T. \& Turin H. 1994: Towards a method for biological assessment of habitat quality using carabid samples (Coleoptera, Carabidae). In Desender K., Dufrêne M., Loreau M., Luff M.L. \& Maelfait J.-P. (eds): Carabid Beetles: Ecology and Evolution. Kluwer, Dordrecht, pp. 305-312.

Helden A.J. \& LeATHER S.R. 2004: Biodiversity on urban roundabouts - Hemiptera, management and the species-area relationship. Basic Appl. Ecol. 5: 367-377.

HeliövaARA K. \& VäISÄnen R. 1993: Insects and Pollution. CRC press, Boca Raton, 393 pp.

Holopainen J.K., Kainulainen J., Oksanen J., Wulff A. \& KÄRENLAMPI L. 1991: Effect of exposure to fluoride, nitrogen compunds and $\mathrm{SO}_{2}$ on the numbers of spruce shoot aphids on Norway spruce seedlings. Oecologia 86: 51-56.

Holopainen J.K., BRAUn S. \& FlÜCKIGER W. 1994: The response of spruce shoot aphid Cinara pilicornis Hartig to ambient and filtered air at two elevations and pollution climates. Environ. Pollut. 86: 233-238.

Hornung E., Tóthmérész B., Magura T. \& Vilisics F. 2007: Changes of isopod assmeblages along an urban-suburbanrural gradient in Hungary. Eur. J. Soil Biol. 43: 158-165. 
Houlden G., McNeill S., Aminukano M. \& Bell J.N.B. 1990: Air pollution and agricultural aphid pests. I: Fumigation experiments with $\mathrm{SO}_{2}$ and $\mathrm{NO}_{2}$. Environ. Pollut. 67: 305-314.

Hunter M.C. \& Hunter M.D. 2008: Designing for conservation of insects in the built environment. Insect Conserv. Divers. 1: 189-196.

IRMLER U. 2003: The spatial and temporal pattern of carabid beetles on arable fields in northern Germany (SchleswigHolstein) and their value as ecological indicators. Agric. Ecosyst. Environ. 98: 141-151.

Ishitami M., Kotze D.J. \& Niemelä J. 2003: Changes in carabid beetles assemblages across an urban-rural gradient in Japan. Ecography 26: 481-489.

JoNES R.A. 2003: The 2001 presidential address - part 2. A celebration of urban entomology. Br. J. Entomol. Nat. Hist. 16: 109-121.

Jones M.P. \& PAINE T.D. 2006: Detecting changes in insect herbivore communities along a pollution gradient. Environ. Pollut. 143: 377-387.

KadAS G. 2011: Green Roofs and Biodiversity: Can Green Roofs Provide Habitat for Invertebrates in an Urban Environment? Lambert Academic Publishing, London.

Kazemi F., Beecham S. \& Gibbs J. 2009: Streetscale bioretention basins in Melbourne and their effect on local biodiversity. Ecol. Engineer. 35: 1454-1465.

Keep B. 2006: A Study of Spiders (Aranea), Lepidoptera Caterpillars, Agromyzidae and Lepidoptera Leaf Miners and the Species-Area Relationship. MSc Thesis, Imperial College, London.

Kegel B. 1990: The distribution or carabid beetles in the urban area of West Berlin. In Stork N.E. (ed.): The Role of Ground Beetles in Ecological and Environmental Studies. Intercept, Andover, pp. 325-329.

KielHorn K.-H., Keplin B. \& Hüttl R.F. 1999: Ground beetle communities on reclaimed mine spoil: Effects of organic matter application and revegetation. Plant Soil 213: 117-125.

King T.G. \& GREEN S.C. 1995: Factors affecting the distribution of pavement ants (Hymenoptera: Formicidae) in Atlantic Coast urban fields. Entomol. News 106: 224-228.

Kinnunen H., JärvekäInen K., Pakkala T. \& Tiainen J. 1996 The effect of isolation on the occurrence of farmland carabids in a fragmented landscape. Ann. Zool. Fenn. 33: 165-171.

KitAhARA M. \& FUIII K. 1994: Biodiversity and community structure of temperate butterfly species within a gradient of human disturbance: An analysis based on the concept of generalist vs. specialist strategies. Res. Popul. Ecol. 36: 187-199.

Klausnitzer B. \& Richter K. 1983: Presence of an urban gradient demonstrated for carabid associations. Oecologia 59: 79-82.

KoH L.P. \& SoDHI N.S. 2004: Importance of reserves, fragments, and urban parks for butterfly conservation in a tropical urban landscape. Ecol. Appl. 14: 1695-1708.

KoIvula M. 2002: Alternative harvesting methods and boreal carabid beetles (Coleoptera, Carabidae). Forest Ecol. Manag. 167: 103-121.

Koivula M.J. \& Vermeulen H.J.W. 2005: Highways and forest fragmentation - effects on carabid beetles (Coleoptera, Carabidae). Landsc. Ecol. 20: 911-926.

Koivula M.J., Kotze D.J. \& Salokannel J. 2005: Beetles (Coleoptera) in central reservations of three highway roads around the city of Helsinki, Finland. Ann. Zool. Fenn. 42: 615-626.

KONVICKA M. \& KADLEC T. 2011: How to increase the value of urban areas for butterfly conservation? A lesson from Prague nature reserves and parks. Eur. J. Entomol. 108: 219-229.
Kotze D.J. \& O’Hara R.B. 2003: Species decline - but why? Explanations of carabid beetle (Coleoptera, Carabidae) declines in Europe. Oecologia 135: 138-148.

LEATHER S.R. \& Helden A.J. 2005: Magic roundabouts? Teaching conservation in schools and universities. J. Biol. Educ. 39: 102-107.

LightFoot D.C. \& Whitford W.G. 1990: Phytophagous insects enhance nitrogen flux in a desert creosotebush community. Oecologia 82: 18-25.

LÖVEI G.L. \& SuNDERLAND K.D. 1996: Ecology and behaviour of ground beetles (Coleoptera: Carabidae). Annu. Rev. Entomol. 41: 231-256.

Löver G.L., Magura T., Tóthmérész B. \& KöDöвöcz V. 2006: The influence of matrix and edges on species richness patterns of ground beetles (Coleoptera: Carabidae) in habitat islands. Global Ecol. Biogeogr. 15: 283-289.

LuCE A. \& CRowe M. 2001: Invertebrate terrestrial diversity along a gravel road on Barrie Island, Ontario, Canada. Great Lakes Entomol. 34: 55-60.

Luff M.L. 2007: The Carabidae (Ground Beetles) of Britian and Ireland. Royal Entomological Society, London, $247 \mathrm{pp}$.

LusSENHOP J. 1973: The soil arthropod community of a Chicago expressway margin. Ecology 54: 1124-1137.

MADER H.-J. 1984: Animal habitat isolation by roads and agricultural fields. Biol. Conserv. 29: 81-96.

Mader H.-J., Schell C. \& Kornacker P. 1990: Linear barriers to arthropod movements in the landscape. Biol. Conserv. 54: 209-222.

Magura T. 2002: Carabids and forest edge: spatial pattern and edge effects. Forest Ecol. Manag. 157: 23-37.

Magura T. \& Tóthmérész B. 1997: Testing edge effect on carabid assemblages in an oak-hornbeam forest. Acta Zool. Acad. Sci. Hung. 43: 303-312.

Magura T., Tóthmérész B. \& MolnÁr T. 2000: Spatial distribution of carabids along grass-forest transects. Acta Zool. Acad. Sci. Hungar. 46: 1-17.

Magura T., Tóthmérész B. \& MolnÁr T. 2001: Forest edge and diversity: carabids along forest-grassland transects. Biodiversity Conserv. 10: 287-300.

Magura T., Tóthmérész B. \& Molnár T. 2004: Changes in carabid beetle assemblages along an urbanisation gradient in the city of Debrecen, Hungary. Landsc. Ecol. 19: 747-759.

Magura T., Tóthmérész B. \& Lövei G.L. 2006: Body size inequality of carabids along an urbanisation gradient. Basic Appl. Ecol. 7: 472-482.

Magura T., LÖvei G.L. \& TÓTHMÉrész B. 2008a: Timeconsistent rearrangement of carabid beetle assemblages by an urbanisation gradient in Hungary. Acta Oecol. 34: 233-243.

Magura T., Tóthmérész B. \& MolnÁr T. 2008b: A specieslevel comparison of occurrence patterns in carabids along an urbanisation gradient. Landsc. Urban Planning 86: 134-140.

Magura T., Horvath R. \& Tóthmérész B. 2010: Effects of urbanization on ground dwelling spiders in forest pathches in Hungary. Landsc. Ecol. 25: 621-624.

Masters G.J. \& McNeill S. 1996: Evidence that plant varieties respond differently to $\mathrm{NO}_{2}$ pollution as indicated by resistance to insect herbivores. Environ. Pollut. 91: 351-354.

Matteson K.C., Ascher J.S. \& Langellotto G.A. 2008: Bee richness and abundance in New York City Urban Gardens. Ann. Entomol. Soc. Am. 101: 140-150.

MatTSON W.J. 1980: Herbivory in relation to plant nitrogen content. Annu. Rev. Ecol. Syst. 11: 119-161.

McDonnell M.J. \& Pickett S.T.A. 1990: Ecosystem structure and function along urban-rural gradients: an unexploited opportunity for ecology. Ecology 71: 1232-1237. 
McGeoch M.A. \& Chown S.L. 1997: Impact of urbanization on a gall-inhabiting Lepidoptera assemblage: the importance of reserves in urban areas. Biodiv. Conserv. 6: 979-993.

McGuinness K.A. 1984: Equations and explanations in the study of species-area curves. Biol. Rev. 59: 423-440.

MCInTYRe N.E. 2000: Ecology of urban arthropods: a review and a call to action. Ann. Entomol. Soc. Am. 93: 825-835.

McIntyre N.E. \& Hostetler M.E. 2001: Effects of urban land use on pollinator (Hymenoptera: Apoidea) communities in a desert metropolis. Basic Appl. Ecol. 2: 209-218.

Mcintyre N.E., Rango J., Fagan W.F. \& Faeth S.H. 2001: Ground arthropod community structure in a heterogeneous urban environment. Landsc. Urban Planning 52: 257-274.

MacIvor J. S., \& Lundholm J. 2011: Insect species composition and diversity on intensive green roofs and adjacent levelground habitats. Urban Ecosyst. 14: 225-241.

McNeill S. \& WhittaKer J.B. 1990: Air pollution and treedwelling aphids. In Watt A.D., Leather S.R., Hunter S.R., Hunter M.B. \& Kidd N.A.C. (eds): Population Dynamics of Forest Insects. Intercept, Andover, pp. 195-208.

Melis C., Olsen C.B., Hyllvang M., Gobbi M., Stokke B.G. \& RøskAFt E. 2010: The effect of traffic intensity on ground beetles (Coleoptera: Carabidae) assemblages in central Sweden. J. Insect Conserv. 14: 159-168.

Miyashita T., Shinkai A. \& Chida T. 1998: The effects of forest fragmentation on web spider communities in urban areas. Biol. Conserv. 86: 357-364.

Monteys V.S. 1992: Spread of the Southern African Lycaenid butterfly, Cacyreus marshalli Butler, 1898, (Lep: Lycaenidae) in the Balearic Archipelago (Spain) and considerations on its likely introduction to continental Europe. J. Res. Lepidopt. 31: 24-34.

Morris M.G. 2000: The effects of structure and its dynamics on the ecology and conservation of arthropods in British grasslands. Biol. Conserv. 95: 129-142.

Mossakowski D., Främbs H. \& Baro A. 1990: Carabid beetles as indicators of habitat destruction caused by military tanks. In Stork N.E. (ed.): The Role of Ground Beetles in Ecological and Environmental Studies. Intercept, Andover, pp. 237-243.

Munguira M.L. \& Thomas J.A. 1992: Use of road verges by butterfly and burnet populations, and the effect of roads on adult dispersal and mortality. J. Appl. Ecol. 29: 316-329.

Muskett C.J. \& Jones M.P. 1980: The dispersal of lead, cadmium and nickel from motor vehicles and effects on roadside invertebrate macrofauna. Environ. Pollut. (A) 23: 231-242.

National Statistics 2007: News Release: UK Population Grows to 60,587,000 in Mid-2006. London: National Statisics. [Online] Available from: http://www.statistics.gov. uk/pdfdir/popest0807.pdf [Accessed November 2007].

Niemelä J. 1999: Ecology and urban planning. Biodiv. Conserv. 8: $119-131$.

Niemelä J. 2001: Carabid beetles (Coleoptera: Carabidae) and habitat fragmentation: a review. Eur. J. Entomol. 98: $127-132$.

Niemelä J., Kotze D.J., Venn S., Penev L., Stoyanov I., Spence J., Hartley D. \& DE OCA E.M. 2002: Carabid beetle assemblages (Coleoptera, Carabidae) across urban-rural gradients: an international comparison. Ladsc. Ecol. 17: 387-401.

NowAKOwSKi E. 1986: Structure of soil click beetle (Coleoptera, Elateridae) communities in urban green areas of Warsaw. Memorab. Zool. 41: 81-102.

Odum E.P. 1969: The strategy of ecosystem development. Science 164: 262-270.

Office for National Statistics 2009: Rural/Urban Definition Directgov. [Online] Available from: http://www.statistics. gov.uk/geography/rudn.asp [Accessed October 2009]. London.

Okuma C. \& Kitazawa Y. 1982: Spider fauna on the campus of $\mathrm{UOEH}$ and in an adjacent natural forest. J. Univ. Occup. Environ. Health 4: 1-9.

Oliver I. \& Beattie A.J. 1996: Designing a cost-effective invertebrate survey: A test of methods for rapid assessment of biodiversity. Ecol. Appl. 6: 594-607.

OwEN D.F. 1971: Species diversity in butterflies in a tropical garden. Biol. Conserv. 3: 191-198.

OWEN J. 1983: Effects of contrived plant diversity and permanent succession on insects in English suburban gardens. In Franie G.W. \& Koehler C.S. (eds): Urban Entomology; Interdisciplinary Perspectives. Praeger, New York, pp. 395-422.

Owen J. \& Owen D.F. 1975: Suburban gardens: England's most important nature reserve? Environ. Conserv. 2: 53-59.

Palmer S.C.F., Cape J.N., Truscott A.-M., Black H.I.J., Tang Y.S., Swaine E., van Dijk N., Smart S.M., Sutton M.A. \& Fowlen D. 2004: Biodiversity in Roadside Verges: Final Report to the Scottish Executive Environment and Rural Affairs Department. Centre for Ecology and Hydrology, UK.

Paoletti M.G. \& Hassall M. 1999: Woodlice (Isopoda: Oniscidea): their potential for assessing sustainability and use as bioindicators. Agric. Ecosyst. Environ. 74: 157-165.

Pizzolotto R. 1994: Ground beetles (Coleoptera, Carabidae) as a tool for environmental management: a geographic information system based on carabids and vegetation for the Karst near Trieste (Italy). In Desender K., Dufrêne M., Loreau M., Luff M.L. \& Maelfait J.-P. (eds): Carabid Beetles: Ecology and Evolution. Kluwer, Dordrecht, pp. 343-351.

Population Division Department of Economic and Social Affairs. 2001: World Urbanization Prospects: The 1999 Revision. Population Division, Department of Economic and Social Affairs. [Online] Available from: http://www.un.org/ esa/population/publications/wup1999/wup99.htm [Accessed November 2007]. New York.

Port G.R. \& ThOMPSON J.R. 1980: Outbreaks of insect herbivores on plants along motorways in the United Kingdom. $J$. Appl. Ecol. 17: 649-656.

Pouyat R.V., Parmelee R.W. \& Carreiro M.M. 1994: Environmental effects of forest soil-invertebrate and fungal densities in oak stands along an urban-rural land use gradient. Pedobiologia 38: 385-399.

Preston F.W. 1962: The canonical distribution of commonness and rarity: part I. Ecology 43: 185-215.

PRZYBYLSKI Z. 1979: The effect of automobile exhaust gases on the arthropods of cultivated plants, meadows and orchards. Environ. Pollut. (A) 19: 157-161.

Pyle R., Bentzien M. \& Opler P. 1981: Insect conservation. Annu. Rev. Entomol. 26: 233-258.

Rainio J. \& Niemelä J. 2003: Ground beetles (Coleoptera: Carabidae) as bioindicators. Biodiv. Conserv. 12: 487-506.

RANTA E. \& Ås S. 1982: Non-random colonization of habitat islands by carabid beetles. Ann. Zool. Fenn. 19: 175-181.

RaO R.S.P. \& GIRISH M.K.S. 2007: Road kills: Assessing insect casualties using flagship taxon. Current Sci. 92: 830-837.

Raupp M.J., Shrewsbury P.M. \& Herms D.A. 2010: Ecology of herbivorous arthropods in urban landscapes. Annu. Rev. Entomol. 55: 19-38.

RuszcZYK A. 1986: Distribution and abundance of butterflies in the urbanization zones of Porto Alegre, Brazil. J. Res. Lepidopt. 25: 157-178.

SaArinen K., Valtonen A., Jantunen J. \& SaArnio S. 2005: Butterflies and diurnal moths along road verges: Does road type affect diversity and abundance? Biol. Conserv. 123: 403-412. 
Sadler J.P., Small E.C., Fiszpan H., Telfer M.G. \& Niemelä J. 2006: Investigating environmental variation and landscape characteristics of an urban-rural gradient using woodland carabid assemblages J. Biogeogr. 33: 1126-1138.

SAlt D.T. \& WhitTaKer J.B. 1995: Populations of root-feeding aphids in the Liphook forest fumigation experiment. Plant Cell Environ. 18: 321-325.

Samways M.J., Osborn R. \& Carliel F. 1997: Effects of a highway on ant (Hymenoptera: Formicidae) species composition and abundance, with a recommendation for roadside verge width. Biodiv. Conserv. 6: 903-913.

Sattler T., Duelli P., Obrist M.K., Arlettaz R. \& Moretti M. 2010: Response of arthropod species richness and functional groups to urban habitat structure and management. Landsc. Ecol. 25: 941-954.

Schmitz G. 1996: Urban ruderal sites as secondary habitats for phytophagous insects. Verh. Ges. Okol. 26: 581-585.

SCOTT W.A. \& ANDERson R. 2003: Temporal and spatial variation in carabid assemblages from the United Kingdom Environmental Change Network. Biol. Conserv. 110: 197-210.

Seibert H.C. \& Conover J.H. 1991: Mortality of vertebrates and invertebrates on and Athens County, Ohio, Highway. Ohio J. Sci. 91: 163-166.

ShapIRo A.M. 2001: The Californian urban butterfly fauna is dependent on alien plants. Divers. Distrib. 8: 31-40.

Shapiro A.M. 2006: Poanes melane (Hesperiidae) ovipositing on an Australian grass naturalized in California. J. Lepidopt. Soc. 60: 101.

Shapiro A.M. \& Shapiro A.R. 1973: The ecological associations of the butterflies of Staten Island (Richmond County, New York). J. Res. Lepidopt. 12: 65-128.

Shrewsbury P.M. \& Leather S.R. 2012: Using biodiversity for pest suppression in urban landscapes. In Gurr G.M., WrattenS.D., Snyder W.E. \& Read D.M.Y. (eds): Biodiversity and Insect Pests: Key Issues for Sustainable Management. John Wiley \& Sons, Oxford, pp. 294-308.

Siemann E., Tilman D., HaArstad J. \& Ritchie M. 1998: Experimental tests of the dependence of arthropod diversity on plant diversity. Am. Nat. 152: 738-750.

Sims I.R. \& Reynolds P.J. 1999: Effects of atmospheric pollution on a lichenophagous lepidopteran. Ecotoxicol. Environ. Safety 42: 30-34.

Small E., Sadler J.P. \& Telfer M.G. 2006: Do landscape factors affect brownfield carabid assemblages? Sci. Total Environ. 360: 205-222.

Smith R.M., Gaston K.J., Warren P.H. \& Thompson K. 2006a: Urban domestic gardens (VIII): environmental correlates of invertebrate abundance. Biodiv. Conserv. 15: 2515-2545.

Smith R.M., Warren P.H., Thompson K. \& Gaston K.J. 2006b: Urban domestic gardens (VI): environmental correlates of invertebrate species richness. Biodiv. Conserv. 15: 24152438.

Southwood T.R.E. 1975: The dynamics of insect populations. In Pimentel D. (ed.): Insects, Science and Society. Academic Press, New York, pp. 151-199.

Spence J.R., Langor D.W., Niemelä J., Cárcamo H.A. \& Currie C.R. 1996: Northern forestry and carabids: the case for concern about old-growth species. Ann. Zool. Fenn. 33: 173-184.

Spencer H.J., Scott N.E., Port G.R. \& Davison A.W. 1988: Effects of roadside conditions on plants and insects. I. Atmospheric conditions. J. Appl. Ecol. 25: 699-707.

Stamp G.C. 2006: Beetle and Birds on Roundabouts: Fragmented Urban Habitats in Biodiversity Conservation and the Species-Area Relationship. MSc Thesis, Imperial College, London.
Strauss B. \& Biedermann R. 2006: Urban brownfields as temporary habitats: driving forces for the diversity of phytophagous insects. Ecography 29: 928-940.

Su Z., Zhang R. \& QIU J. 2011: Decline in the diversity of willow trunk-dwelling weevils (Coleoptera: Curculionidae) as result of urban expansion in Beijing, China. J. Insect Conserv. 15: $367-377$.

Synder B.A. \& Hendrix P.F. 2008: Current and potential roles of soil macroinvertebrates (eathworms, millipedes, and isopods) in ecological restoration. Restor. Ecol. 16: 629-639.

Thomas J.A., Snazell R.G. \& Ward L.K. 2002: Are roads harmful or potentially beneficial to butterflies and other insects? In Sherwood B., Cutler D. \& Burton J. (eds): Wildlife and Roads: the Ecological Impact. Imperial College Press, London, pp. 203-222.

TISCHLER W. 1973: Ecology of arthropod fauna in man-made habitats. Zool. Anz. 191: 157-161.

Trumble J.T., Hare J.D., Mussleman R.C. \& McCool P.M. 1987: Ozone-induced changes in host-plant suitability: interactions of Keiferia lycopersicella and Lycopersicon esculentum. J. Chem. Ecol. 13: 203-218.

Tyler G., Balsberg Pahlsson A.-M., Bengtsson G., BaAth E. \& TRANVIK L. 1989: Heavy-metal ecology of terrestrial plants, microorganisms and invertebrates. Water Air Soil Pollut. 47: 189-215.

Valtonen A., SaArinen K. \& Jantunen J. 2007: Intersection reservations as habitats for meadow butterflies and diurnal moths: Guidelines for planning and management. Landsc. Urban Planning 79: 201-209.

VENN S. \& RoKala K. 2005: Effects of grassland management strategy on the carabid fauna of urban parks. In Sklodowski J., Huruk S., Barševskis A. \& Tarasiuk S. (eds): Protection of Coleoptera in the Baltic Sea Region. Warsaw Agricultural University Press, Warsaw, pp. 65-75.

Venn S.J., Kotze D.J. \& Niemelä J. 2003: Urbanization effects on carabid diversity in boreal forests. Eur. J. Entomol. 100: $73-80$.

VermeUlen H.J.W. 1993: The composition of the carabid fauna on poor sandy road-side verges in relation to comparable open areas. Biodiv. Conserv. 2: 331-350.

Viskari E.-L., Surakka J., Pasanen P., Mirme A., Kössi S., RUUSKANEN J. \& Holopainen J.K. 2000: Responses of spruce seedlings (Picea abies) to exhaust gas under laboratory conditions - I. Plant-insect interactions. Environ. Pollut. 107: 89-98.

Walsh P.J., Leather S.R. \& Day K.R. 1993: The effects of aerial application of fenitrothion on the carabid community of defoliated and undefoliated lodgepole pine, Pinus contorta. $J$. Appl. Entomol. 115: 134-138.

WARRINGTON S. 1987: Relationship between $\mathrm{SO}_{2}$ dose and growth of the aphid Acyrthosiphon pisum on peas. Environ. Pollut. 43: 155-162.

WARRINGTON S. \& WhittaKer J.B. 1990: Interactions between Sitka spruce, the green spruce aphid, sulphur dioxide pollution and drought. Environ. Pollut. 65: 363-370.

Warrington S., Mansfield T.A. \& WhitTaKer J.B. 1987: Effect of $\mathrm{SO}_{2}$ on the reproduction of pea aphids Acyrthosiphon pisum and the impact of $\mathrm{SO}_{2}$ and aphids on the growth and yield of peas. Environ. Pollut. 48: 285-294.

Weller B. \& Ganzhorn J.U. 2004: Carabid beetle community composition, body size, and fluctuating asymmetry along an urban-rural gradient. Basic Appl. Ecol. 5: 193-201.

White T.C.R. 1978: The importance of a relative shortage of food in animal ecology. Oecologia 33: 71-86. 
WhItTAKER J.B. 1999: Impacts and responses at population level of herbivorous insects to elevated $\mathrm{CO}_{2}$. Eur. J. Ecol. 96: 149-156.

Williamson P. \& Evans P.R. 1973: A preliminary study of the effects of high levels of inorganic lead on soil fauna. Pedobiologia 13: 16-21.

ZAPPAROLI M. 1997: Urban development and insect biodiversity of the Rome area, Italy. Landsc. Urban Planning 38: 77-86.
ZULKA K.P. 1994: Carabids in a Central European floodplain: sepcies distribution and survival during inundations. In Desender K., Dufrêne M., Loreau M., Luff M.L. \& Maelfait J.-P. (eds): Carabid Beetles: Ecology and Evolution. Kluwer, Dordrecht, pp. 399-405.

Received February 16, 2012; revised and accepted June 18, 2012 